\section{Elements of health education in science coursebooks}

Marcin M. Chrzanowski, Ewa Piszczek

\begin{abstract}
Summary:
Preamble to Core Curriculum of General Education for Gymnasia and Post-Gymnasium Schools provides a really important statement concerning health education: (...) health education is an important task of schools on 3 rd and 4th educational stages. Its goal is to develop an attitude of care for one's own and other people's health and an ability to create a health-friendly environment. The health education is not an individual part of general teaching, thus its contents are included into curriculum of other subjects, especially to science and biology, but not only to science-related subjects). The core curriculum is a foundation not only to build documents connected with didactical planning, but also especially with process of teaching. Additionally all the coursebooks used in school have to be strictly related to goals of education and teaching content written in curriculum and must be approved by the Ministry of Education. The aim of research was to investigate the level of health education contents (included in science core curriculum for classes: 4th to 6th) implementation in all science school books for ISCED 1 to check whether the teaching contents referring to the health education are compatible to the new core curriculum and if it may lead to shaping of the students' health awareness. What is important - the analyse was not aimed at making any ranking of textbooks or choosing the best one.
\end{abstract}

DOI: $10.24131 / 3247.180107$

Key words: science, biology, coursebook, health education, core curriculum, health awareness

received: 13.07.2017; accepted: 23.08.2017; published: 13.12.2017
From a social point of view, it is desirable that existing knowledge on health was adequately utilized, contributing to shaping healthy

behaviour among the population. The mere dissemination of knowledge is not sufficient since the use of it on a daily basis depends on many other factors, in which human attitudes play a significant role. These, in turn, depend on the emotional involvement that results from the position of health in one's hierarchy of values and the sense of responsibility for one's destiny. In a word, there must be an adequate level of motivation to maintain a healthy lifestyle. In addition, the ability to make changes in our lifestyles, adaptability, plays a big role. This feature generally develops as education level increases (Kirschner, 1992)

\section{Health and health education in the curriculum of science and biology}

Adolescence is divided into two phases: early, between 10 and 16 years of age, and late, between 17 and 22/24 (Oleszkowicz, 2011). At this time, especially during the early phase, the views, attitudes, habits and health behaviours are formed and then persisted (late

dr Marcin Chrzanowski: School Subject Teaching Department, Science Subjects Laboratory, Educational Research Institute in Warsaw. Biology Teaching Laboratory. Faculty Instivte in Warsaw, Biogy Teac of Biology, University of Warsaw

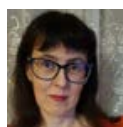

mgr Ewa Piszczek: Zespół Szkół nr 121 w Warszawie (ul. Czerniakowska 128), Chrześcijańskie Gimnazjum „Samuel” w Warszawie (ul. Boremlowska 6/12) stage) (Grysztar and Duplag, 2016). One of the aims of health education is to shape the health awareness of the youth. First few years of early adolescence correspond with pupils in grades 4 to 6 of primary school. In the current educational system, science subjects are integrated at this stage of learning. In the new system, which is to come into force in September 2017, science will be taught in grade 4 , and then separate subjects will be gradually introduced of the curriculum - biology and geography first, then physics, and finally, in grade 7 - chemistry (MEN, 2017). The elements of health education are included in the core curriculum starting with early school education. In the second stage of training (i.e. in grades 4-6) these requirements are listed in: physical education, science and health classes. They also appear in the following subjects: modern language, Polish, ethics, practical and technical classes, computer classes and music (Woynarowska, 2009). In the preamble of the current core curriculum for primary, lower secondary and secondary schools, the following sentence is included: Health education is also an important task of the school, carried out by teachers of many subjects, aiming at shaping the students' ability to care for their own health and the health of other people (MEN 2009). This is a statement of essential importance. It gives a high value to health education among the school's tasks.

Present vs. future curricula - core 2009 and 2017 curricula

\section{Current curriculum}

In the current core curriculum of general education for the secondary phase of the science subject (MEN, 2009), health education appears in four paragraphs and in a number of sub-paragraphs listed in Table 1. 
No. the content of the record

1. Me and my surroundings. Student:

1 lists positive and negative influences on his or her well-being at school and at home and proposes ways to eliminate the negative ones;

2 explains the importance of rest (including sleep), nutrition and physical activity in the proper functioning of the body;

3 mentions the principles of proper learning and applies them in their life;

$4 \quad$ correctly describes a properly designed learning space for a primary school pupil;

5 explains the need for introducing day and week activity schedules; properly arranges and executes his or her schedule during the day;

$6 \quad$ (...) applies safety rules during science observation

9 recognizes and names certain plants (including potted plants) that contain substances that are poisonous or harmful to humans and provides the rules for dealing with them

5. Man and the environment. Student:

5 provides examples of positive and negative impacts the environmental has on human health;

9. Health and health care. Student:

gives examples of the negative impact of selected species of animals, plants, fungi, bacteria and viruses on human health, lists behaviour to prevent and transmit diseases;

2 lists the rules for handling food products from the time of purchase to the time of consumption (expiration date, storage, meal preparation);

lists the principles of proper nutrition and applies them;

4 gives and applies the rules of proper care of your own body (skin, hair, teeth, nails and clothing hygiene);

5 characterizes the basic principles of sight and hearing protection:

6 explains the importance of movement and physical exercise in maintaining health;

gives examples of proper leisure activities, taking into account the safety rules during active games including traffic rules.

8 describes first aid in certain injuries (bruises, sprains, cuts, fractures, bites, stings), can call for help in various situations;

9 provides examples of behaviours and situations that could endanger human health and life (e.g. unexploded ordnance and dud fire, traffic accident, skating or swimming in unauthorised places):

explains the meaning of the symbols placed on cleaning product containers etc. and uses the products according to their intended use

11 lists the basic principles of safety at home, including the use of electrical appliances, the use of gas, water

explains the negative impact of alcohol, nicotine and psychoactive substances on human health, provides suggestions for assertive respond in the event of peer pressures;

13 lists the principles of healthy lifestyle and explains the need to use them;

10. Electrical and magnetic phenomena in science. Student:

4 describes the effects of current flow in household electrical appliances; describes and applies principles of safe handling of electrical appliances;

Table 1: Detailed objectives of health education as covered by the science subject in the second stage of education in the current curriculum

\section{Upcoming curriculum}

Section introducing basics. Learning objectives

The upcoming (applicable for the 4th and 7th grades of the primary school from 1 September 2017) curriculum proposed a slightly different approach to health education. In the 14 February 2017 curriculum, the preamble states: Health education plays an important role in educating and upbringing primary school pupils. The purpose of the school is to develop students' healthy attitudes, including their introduction to hygienic behaviours that are safe for their own and others' health, and to further their knowledge of proper nutrition, physical activity and prevention (MEN 2017). Furthermore, the chapter Science ${ }^{1}$ provides the following description of the general educational objectives: During Science classes, both in the field and in the classroom, students perfect their abilities, under the guidance of the teacher, to respond properly in the event of contact with life and health-threatening organisms. These important issues concerning the structure and hygiene of the human body and its proper care shape the student 's correct behaviour in everyday life $\mathrm{e}^{2,3}$.

1 The Biology chapter states: Health is at the utmost importance of biology teaching, hence the issues related to anatomy, physiology and health protection in the core curriculum for elementary education. (MEN, 2017).

2 The chapter on Education for Safety: First aid is one of the most important skills pupils learn in school. The following health and life safety issues should be addressed at an early stage of education: safety assessment of the site, identification of potential life-threatening symptoms based on simple symptoms, effective call for help, pre-medical life-saving measures (MEN, 2017).

3 An interesting insight related to health education found in the Physical Education subsection: In the core curriculum for primary education, there is a personalistic concept of education and a concept of physical fitness oriented towards health (MEN 2017). 


\section{Introduction. Student achievements}

The upcoming core curriculum describes the socalled student's achievement in the field of natural sciences (Section IV). Health education achievements are listed below.

2. Achievements in human life functions, health, safety and rest. Student:

1. presents the characteristics of selected professions and occupations of people known from the place of residence and professions of public utility: (...) physician, nurse (...), and understands the essence of medical (...) service work;

2. uses emergency telephone numbers, formulates a message - a call for help: Police, Emergency Medical Services, Fire Brigade;

3. presents personal data during a contact with uniformed and medical services, in health and lifethreatening situations;

4. takes care of the hygiene and aesthetics of the their own and their surroundings;

5. reacts appropriately in the event of a threat to their or others' safety or health

6. lists the nutritional values of food products; is aware of the importance of adequate diets to maintain health, reduces the consumption of lownutrient and unhealthy foods, is modest in eating sweetened products, knows the consequences of eating excessively;

7. prepares meals that maintain health;

8. dresses appropriately for weather conditions, looks for weather information, e.g. using the Internet;

11. is aware of the natural hazards, e.g. sudden changes in weather, hurricanes, torrential rains, storms, droughts and their consequences: flood, fire, lightning; identifies appropriate responses in such situations;
Learning objectives in the course of science for the fourth grade of primary school

General learning objectives regarding health education: Listed below.

1. In terms of knowledge - none

2. In terms of skills and knowledge application:

- Use of acquired knowledge of own body structure and hygiene in everyday life.

- Applying principles of care for own health, including disease prevention

3. In the field of shaping attitudes - upbringing

- Proper response in life and health-threatening situations.

- Improving the ability of care for one's body and surroundings

Learning objectives in the course of biology for grades 5 to 8 of primary school

The learning objectives for the course of biology were formulated according a different system than the one used for science. They are divided (as in the current curriculum) into general objectives - learning objectives and specific objectives - teaching content. The elements of health education are presented in Chapter $\mathrm{V}$ of the learning objectives:

V. Knowledge of human health determinants. Student:

1) analyses the relationship between their behaviour and their health and recognizes situations requiring medical attention;

2) explains the importance of blood donations and organ transplants.

Course content for 4 grade science and 5 to 8 grade biology education for elementary school

The teaching content previously included in the curriculum of the subject of science regarding the elements of health education, were divided into several stages (Ta- ble 2). It may seem that the number of records is much higher, but keep in mind that the material from junior high school is also included in grades 7 and 8 . In carrying out the core curriculum in biology, we recommend (...) the following content and requirements: 1) Grade 5: Section I and Part of the Section II (paragraphs 1-6); 2) Grade 6: Part of the Section II, (Section II paragraph 7); 3) Grade 7: Section III and IV; 4) Grade 8: Section V-VIII (MEN, 2017).

It is worth mentioning that most of the teaching content in the current core curriculum, which is related to health education, has more or less direct equivalents in a 4th grade science course and a biology course for grades 5 to 8 in the forthcoming curriculum, thus the prepared analysis can be universal. In Table 3, the corresponding subparagraphs for grade 4 of science and biology for grades 5 to 8 of the upcoming curriculum were applied to the teaching content of the current grade 4 to 6 science curriculum.

\section{Health awareness and students' social competences, knowledge and skills}

The terms knowledge, skills and social competences, as recommended by the European Parliament and the Council of 23 April 2008, can be cited by the Dictionary of Basic Terms for the national qualification system (Sławiński, Dębowski and others 2014):

- Social competence is defined as the ability to shape one's own development and the autonomous and responsible participation in professional and social life, including the ethical context of one's own conduct,

- Knowledge (sometimes referred to as "information") is defined as a set of facts, principles, theories and practice descriptions adapted in the learning process related to a learning field or an occupational activity, 


\begin{tabular}{|c|c|c|c|}
\hline No. & subject & grade & the content of the record \\
\hline & & & science \\
\hline \multicolumn{4}{|c|}{ III. Weather, weather components, weather observation. Student: } \\
\hline 7. & science & IV & $\begin{array}{l}\text { describes the principles of safe behaviour during the occurrence of } \\
\text { dangerous weather conditions (storm, hurricane, snowstorm); }\end{array}$ \\
\hline \multicolumn{4}{|r|}{ V. Me and my surroundings. Student: } \\
\hline 1 & \multirow{9}{*}{ science } & \multirow{9}{*}{ IV } & $\begin{array}{l}\text { proposes types of leisure and defines safety rules associated with } \\
\text { them; }\end{array}$ \\
\hline 2 & & & $\begin{array}{l}\text { describes the pathways of pathogen infiltration into the human } \\
\text { body, describes ways of preventing diseases; }\end{array}$ \\
\hline 4 & & & $\begin{array}{l}\text { interprets signs of substances harmful to health: irritating, toxic, cor- } \\
\text { rosive and explosive; }\end{array}$ \\
\hline 5 & & & $\begin{array}{l}\text { gives the rules for behaviour and first aid in case of a bite, sting, and } \\
\text { consumption or contact with a poisonous plant; }\end{array}$ \\
\hline 6 & & & $\begin{array}{l}\text { recognizes poisonous plants and animals that are venomous or pose } \\
\text { a threat to life and health; }\end{array}$ \\
\hline 7 & & & presents basic principles of tending to a damaged skin; \\
\hline 8 & & & $\begin{array}{l}\text { explains what an addiction is, gives examples and describes the con- } \\
\text { sequences; explains why you should not take stimulants and energiz- } \\
\text { ers or use cell phones for too long; }\end{array}$ \\
\hline 9 & & & $\begin{array}{l}\text { identifies harmful substances by packaging: irritating, toxic, corrosive } \\
\text { and explosive and explains their significance; }\end{array}$ \\
\hline 10 & & & $\begin{array}{l}\text { describes the principles of a healthy lifestyle (including healthy eat- } \\
\text { ing). }\end{array}$ \\
\hline \multicolumn{4}{|r|}{ VI. Natural environment of the nearest area. Student: } \\
\hline 10 & science & IV & $\begin{array}{l}\text { recognizes common edible and poisonous mushrooms, describes } \\
\text { the importance of fungi in the environment and in human life; }\end{array}$ \\
\hline \multicolumn{4}{|r|}{ biology } \\
\hline \multicolumn{4}{|c|}{ II. Diversity of life - section 2. Viruses - non-cellular forms of matter. Student: } \\
\hline 2 & biology & V & $\begin{array}{l}\text { describes the path of spread and the principles of preventing diseas- } \\
\text { es caused by viruses (influenza, smallpox, rubella, mumps, measles, } \\
\text { AIDS). }\end{array}$ \\
\hline
\end{tabular}

Table 2: Specific learning objectives for health education covered by the 4th grade science course and the biology course in grades 5 to 8 . (2nd educational stage).

\begin{tabular}{|c|c|c|c|}
\hline No. & subject & grade & the content of the record \\
\hline \multicolumn{4}{|c|}{ II. Diversity of life - section 3. Bacteria - unicellular organisms. Student: } \\
\hline 4 & \multirow[t]{2}{*}{ biology } & \multirow[t]{2}{*}{$\mathrm{v}$} & $\begin{array}{l}\text { describes the path of spread and the principles of preventing dis- } \\
\text { eases caused by bacteria (tuberculosis, lyme disease, tetanus, salmo- } \\
\text { nellosis); }\end{array}$ \\
\hline 5 & & & $\begin{array}{l}\text { explains the importance of bacteria in the environment and for hu- } \\
\text { mans. }\end{array}$ \\
\hline \multicolumn{4}{|c|}{ II. Diversity of life - section 4. Protists - organisms of a diverse cell structure. Student: } \\
\hline 4 & biology & $\mathrm{v}$ & $\begin{array}{l}\text { presents pathways of infection and principles of preventing diseases } \\
\text { caused by protists (toxoplasmosis, malaria). }\end{array}$ \\
\hline \multicolumn{4}{|c|}{ II. Diversity of life - section 6. Mushrooms - heterotrophic organisms. Student: } \\
\hline 5 & biology & V & shows the importance of fungi in science and for humans. \\
\hline \multicolumn{4}{|c|}{ II. Diversity of Life - section 7. Diversity and unity of the animal world: (3) Flatbeds - pupil: } \\
\hline d & \multirow[t]{2}{*}{ biology } & \multirow[t]{2}{*}{$\mathrm{VI}$} & $\begin{array}{l}\text { presents the path of invasion of parasitic platelets and discusses } \\
\text { ways of preventing diseases caused by selected parasites (taenia } \\
\text { solium, taenia saginata) }\end{array}$ \\
\hline e & & & explains the importance of flatworms in science and for humans; \\
\hline \multicolumn{4}{|c|}{ II. Diversity of life - section 7. Diversity and unity of the animal world: (4) nematode - pupil: } \\
\hline c & \multirow[t]{2}{*}{ biology } & \multirow[t]{2}{*}{ VI } & $\begin{array}{l}\text { presents the path of invasion of parasitic nematodes (trichina worm, } \\
\text { worms and pinworm) and discusses ways of preventing human dis- } \\
\text { eases caused by these parasites }\end{array}$ \\
\hline$d$ & & & presents the importance of nematodes in science and for humans; \\
\hline \multicolumn{4}{|c|}{ II. Diversity of life - section 7. Diversity and unity of the animal world: (6) Arthropods - pupil: } \\
\hline c & biology & VI & $\begin{array}{l}\text { explains the importance of arthropods (including forms of parasites } \\
\text { and pests) in science and for humans; }\end{array}$ \\
\hline & & & III. Human body - section 2 Skin. Student: \\
\hline 3 & \multirow{3}{*}{ biology } & \multirow{3}{*}{ VII } & $\begin{array}{l}\text { explains the need for medical consultation in the event of any dis- } \\
\text { turbing changes in the skin; }\end{array}$ \\
\hline 4 & & & $\begin{array}{l}\text { gives examples of skin diseases (skin mycoses, melanoma) and the } \\
\text { principles of its prevention; }\end{array}$ \\
\hline 5 & & & $\begin{array}{l}\text { determines the association between excessive exposure to UV radia- } \\
\text { tion and increased risk of skin cancer development and progression. }\end{array}$ \\
\hline \multicolumn{4}{|c|}{ III. Human organism - section 3 Musculoskeletal system. Student: } \\
\hline 4 & \multirow{2}{*}{ biology } & \multirow{2}{*}{ VII } & $\begin{array}{l}\text { explains the necessity of physical activity for the proper construction } \\
\text { and functioning of the musculoskeletal system; }\end{array}$ \\
\hline 5 & & & $\begin{array}{l}\text { gives examples of musculoskeletal disorders (spinal curvature, flatu- } \\
\text { lence, rickets, osteoporosis) and the principles of their prevention. }\end{array}$ \\
\hline
\end{tabular}




\begin{tabular}{|c|c|c|c|}
\hline No. & subject & grade & the content of the record \\
\hline \multicolumn{4}{|c|}{ III. Human organism - section 4 Digestive system and nutrition. Student: } \\
\hline 2 & \multirow{6}{*}{ biology } & \multirow{6}{*}{ VII } & $\begin{array}{l}\text { recognizes (in diagrams, drawings, models, etc.) the types of teeth } \\
\text { and determines their importance in mechanical food processing; } \\
\text { presents the causes of caries and the principles of its prevention; }\end{array}$ \\
\hline 3 & & & $\begin{array}{l}\text { presents food sources and explains the importance of nutrients } \\
\text { (proteins, sugars, fats, vitamins, minerals and water) for the proper } \\
\text { functioning of the body; plans and conducts experiments to detect } \\
\text { the presence of selected nutrients in food products; }\end{array}$ \\
\hline 5 & & & $\begin{array}{l}\text { analyses the effects of some vitamin (A, D, K, C, B6, B12) and mineral } \\
(\mathrm{Mg}, \mathrm{Fe}, \mathrm{Ca}) \text { deficiencies in the body and the effects of improper } \\
\text { vitamin and mineral supplementation; }\end{array}$ \\
\hline 6 & & & $\begin{array}{l}\text { presents the role of fibre in the functioning of the digestive system } \\
\text { and explains the need for systematic consumption of fruits and } \\
\text { vegetables; }\end{array}$ \\
\hline 7 & & & $\begin{array}{l}\text { explains the need for a diversified diet, that is adapted to the needs } \\
\text { of the body (age, sex, health, physical activity, etc.), calculates the } \\
\text { body mass index, presents and analyses the health consequences } \\
\text { of inappropriate nutrition (obesity, overweight, anorexia, bulimia, } \\
\text { diabetes); }\end{array}$ \\
\hline 8 & & & $\begin{array}{l}\text { gives examples of gastrointestinal diseases (hepatitis A, hepatitis B, } \\
\text { hepatitis C, gastric and duodenal ulcers, food poisoning, colorectal } \\
\text { cancer) and the principles of their prevention. }\end{array}$ \\
\hline \multicolumn{4}{|c|}{ III. Human organism - section 5 Cardiovascular system. Student: } \\
\hline 5 & \multirow{4}{*}{ biology } & \multirow{4}{*}{ VII } & $\begin{array}{l}\text { plans and observes the effects of exercise on the changes in heart } \\
\text { rate and blood pressure; }\end{array}$ \\
\hline 6 & & & $\begin{array}{l}\text { analyses the impact of physical activity and the correct diet on the } \\
\text { functioning of the cardiovascular system; }\end{array}$ \\
\hline 7 & & & $\begin{array}{l}\text { gives examples of blood diseases (anaemia, leukaemia), circulatory } \\
\text { system diseases (atherosclerosis, hypertension, myocardial infarc- } \\
\text { tion) and principles of their prevention; }\end{array}$ \\
\hline 8 & & & $\begin{array}{l}\text { explains the need for periodic blood tests and pulse and blood pres- } \\
\text { sure measurements. }\end{array}$ \\
\hline \multicolumn{4}{|r|}{ III. Human organism - section 6 Immune system. Student: } \\
\hline 3 & \multirow{5}{*}{ biology } & \multirow{5}{*}{ VII } & $\begin{array}{l}\text { compares the essence of vaccine and serum operation; gives indica- } \\
\text { tions for their use and explains the need for compulsory vaccination }\end{array}$ \\
\hline 4 & & & $\begin{array}{l}\text { identifies the situation in which a serological conflict occurs and } \\
\text { foresees its effects; }\end{array}$ \\
\hline 5 & & & $\begin{array}{l}\text { presents the importance of transplants and organ transplant con- } \\
\text { sent; }\end{array}$ \\
\hline 6 & & & $\begin{array}{l}\text { identifies allergy as immune system hypersensitivity to the specific } \\
\text { factor; }\end{array}$ \\
\hline 7 & & & identifies AIDS as an immune mechanism disorder. \\
\hline
\end{tabular}

\begin{tabular}{|c|c|c|c|}
\hline No. & subject & grade & the content of the record \\
\hline \multicolumn{4}{|c|}{ III. Human organism - section 7 Respiratory system. Student: } \\
\hline 5 & \multirow{2}{*}{ biology } & \multirow{2}{*}{ VII } & $\begin{array}{l}\text { analyses the effects of smoking (passive and active) and dust pollu- } \\
\text { tion on the condition and functioning of the respiratory system; }\end{array}$ \\
\hline 6 & & & $\begin{array}{l}\text { gives examples of respiratory diseases (quinsy, tuberculosis, lung } \\
\text { cancer) and the principles of their prevention. }\end{array}$ \\
\hline \multicolumn{4}{|c|}{ III. Human organism - section 8 Urinary system and excretion. Student: } \\
\hline 3 & \multirow[t]{2}{*}{ biology } & \multirow[t]{2}{*}{ VII } & $\begin{array}{l}\text { gives examples of urinary tract diseases (urinary tract infections, } \\
\text { kidney stones) and the principles of their prevention; }\end{array}$ \\
\hline 4 & & & explains the need for periodic urine testing \\
\hline \multicolumn{4}{|c|}{ III. Human organism - section 9 The nervous system. Student: } \\
\hline 4 & \multirow[b]{3}{*}{ biology } & \multirow[b]{3}{*}{ VII } & presents ways to deal with stress; \\
\hline 5 & & & $\begin{array}{l}\text { explains the importance of sleep in the proper functioning of the } \\
\text { nervous system; }\end{array}$ \\
\hline 6 & & & $\begin{array}{l}\text { presents the negative impacts on the functioning of the nervous sys- } \\
\text { tem created by some psychoactive substances: alcohol, drugs, dop- } \\
\text { ing, designer drugs, nicotine (including e-cigarettes), or the abuse of } \\
\text { caffeine and certain medications. }\end{array}$ \\
\hline \multicolumn{4}{|r|}{ III. Human organism - section 10 Sensory organs. Student: } \\
\hline 2 & \multirow[t]{2}{*}{ biology } & \multirow[t]{2}{*}{ VII } & $\begin{array}{l}\text { presents the causes and the ways of correcting sight defects (near- } \\
\text { sightedness, farsightedness, astigmatism); }\end{array}$ \\
\hline 4 & & & describes the impact of noise on human health; \\
\hline \multicolumn{4}{|r|}{ III. Human organism - section 11 Endocrine system. Student: } \\
\hline 3 & biology & VII & $\begin{array}{l}\text { explains why you should not take hormonal medications without } \\
\text { consulting your physician. }\end{array}$ \\
\hline \multicolumn{4}{|c|}{ III. Human organism - section 12 Reproduction and development. Student: } \\
\hline 6 & \multirow[b]{2}{*}{ biology } & \multirow[b]{2}{*}{ VII } & presents the principles of preventing sexually transmitted diseases; \\
\hline 7 & & & $\begin{array}{l}\text { explains the need for screening as a means of early breast cancer, } \\
\text { cervical cancer and prostate cancer diagnosis. }\end{array}$ \\
\hline \multicolumn{4}{|r|}{ IV. Homeostasis. Student: } \\
\hline 2 & \multirow{3}{*}{ biology } & \multirow{3}{*}{ VII } & $\begin{array}{l}\text { represents health as a state of balance of the internal environment of } \\
\text { the body and disease as a disorder of homeostasis; }\end{array}$ \\
\hline 3 & & & $\begin{array}{l}\text { analyses the information included with medicines and explains why } \\
\text { you shouldn't take over-the-counter medicines and supplements } \\
\text { without a specific reason; }\end{array}$ \\
\hline 4 & & & $\begin{array}{l}\text { explains that antibiotics and other medicines should be used accord- } \\
\text { ing to doctor's recommendations (dose, time of administration and } \\
\text { duration of treatment) }\end{array}$ \\
\hline
\end{tabular}




\begin{tabular}{|c|c|c|c|}
\hline No. & subject & grade & the content of the record \\
\hline & & & V. Genetics. Student: \\
\hline 5 & \multirow{4}{*}{ biology } & \multirow{4}{*}{ VIII } & $\begin{array}{l}\text { presents tumours to be a result of uncontrolled cell division and } \\
\text { presents factors conducive to their development (e.g. improper diet, } \\
\text { some stimulants, poor lifestyle, UV radiation, environmental pollu- } \\
\text { tion); }\end{array}$ \\
\hline 8 & & & $\begin{array}{l}\text { gives examples of sex-linked diseases (haemophilia, colour-blind- } \\
\text { ness) and describes their inheritance; }\end{array}$ \\
\hline 10 & & & $\begin{array}{l}\text { describes what is a mutation and lists the possible causes of its oc- } \\
\text { currence (spontaneous and mutagenic mutations) and provides } \\
\text { examples of mutagenic factors (UV radiation, X-rays, tobacco smoke } \\
\text { components, mould fungi toxins, HPV virus); }\end{array}$ \\
\hline 11 & & & $\begin{array}{l}\text { gives examples of human genetic disorders associated with muta- } \\
\text { tions (cystic fibrosis, phenylketonuria, Down syndrome). }\end{array}$ \\
\hline
\end{tabular}

\begin{tabular}{|c|c|c|c|c|c|}
\hline \multirow{2}{*}{$\begin{array}{l}\text { Require- } \\
\text { ment No. } \\
\text { (CC 2009) }\end{array}$} & \multirow[b]{2}{*}{ fragment of the content of the record } & \multicolumn{4}{|c|}{ Equivalent record - CC 2017} \\
\hline & & $\begin{array}{l}\text { sci- } \\
\text { ence }\end{array}$ & grade & $\begin{array}{l}\text { biol- } \\
\text { ogy }\end{array}$ & grade \\
\hline \multicolumn{6}{|c|}{ 1. Me and my surroundings. Student: } \\
\hline 1 & $\begin{array}{l}\text { provides the positive and negative influences } \\
\text { on his or her mood ... }\end{array}$ & - & - & III.9.4 & VII \\
\hline 2 & $\begin{array}{l}\text { explains the importance of rest (including sleep) } \\
\text {... }\end{array}$ & - & - & $\begin{array}{l}\text { III.9.4, } \\
\text { III. } 9.5\end{array}$ & VII \\
\hline 3 & $\begin{array}{l}\text { presents the principles of proper learning and } \\
\text { applies them in his or her life; }\end{array}$ & - & - & III.9.4 & VII \\
\hline 4 & $\begin{array}{l}\text { describes a properly designed learning place for } \\
\text { a pupil... }\end{array}$ & - & - & III.9.4 & VII \\
\hline 5 & explains the need for day and week planning... & - & - & III.9.4 & VII \\
\hline 6 & (...) applies safety rules during observation ... & V.6 & IV & & \\
\hline 9 & $\begin{array}{l}\text { recognizes and names some plants (...) contain- } \\
\text { ing poisonous or harmful substances ... }\end{array}$ & - & - & $\begin{array}{c}111.2 .5 \\
\text { III.7.5 } \\
\text { V.5 }\end{array}$ & $\begin{array}{l}\text { VII } \\
\text { VII } \\
\text { VIII }\end{array}$ \\
\hline \multicolumn{6}{|c|}{ 5. Man and the environment. Student: } \\
\hline 5 & $\begin{array}{l}\text { gives examples (...) of the environmental impact } \\
\text { on human health; }\end{array}$ & - & - & $\begin{array}{c}111.2 .5 \\
\text { III.7.5 } \\
\text { V.5 }\end{array}$ & $\begin{array}{l}\text { VII } \\
\text { VII } \\
\text { VIII }\end{array}$ \\
\hline
\end{tabular}

\begin{tabular}{|c|c|c|c|c|c|}
\hline \multicolumn{6}{|c|}{ 9. Health and health care. Student: } \\
\hline 1 & $\begin{array}{l}\text { gives examples of the negative impact of select- } \\
\text { ed species of animals, plants, fungi, bacteria and } \\
\text { viruses on human health, lists ways to prevent } \\
\text { the diseases that are transmitted and caused } \\
\text { by them; }\end{array}$ & $\begin{array}{l}\text { V.2 } \\
\text { Vl. } 10\end{array}$ & $\begin{array}{l}\text { IV } \\
\text { IV }\end{array}$ & $\begin{array}{c}\text { II.2.2 } \\
\text { II.3.4 } \\
\text { II.3.5 } \\
\text { II.7.3.C } \\
\text { II.7.3.d } \\
\text { II.7.6.C } \\
\text { III.6.3 } \\
\text { III. } 6.6 \\
\text { V.10 }\end{array}$ & $\begin{array}{l}\text { VI } \\
\text { VI } \\
\text { VI } \\
\text { VI } \\
\text { VI } \\
\text { VI } \\
\text { VII } \\
\text { VII } \\
\text { VIII }\end{array}$ \\
\hline 2 & lists rules for dealing with food products ... & V.10 & IV & - & - \\
\hline 3 & $\begin{array}{l}\text { lists the principles of proper nutrition and ap- } \\
\text { plies them; }\end{array}$ & V.10 & IV & $\begin{array}{l}\text { III.4.5 } \\
\text { III.4.6 } \\
\text { III.4.7 }\end{array}$ & $\begin{array}{l}\text { VII } \\
\text { VII } \\
\text { VII }\end{array}$ \\
\hline 4 & $\begin{array}{l}\text { gives and applies the rules of caring for their } \\
\text { own body ... }\end{array}$ & V.10 & IV & III.2.4 & VII \\
\hline 5 & $\begin{array}{l}\text { explains the basic principles of the sight and } \\
\text { hearing protection; }\end{array}$ & V.10 & IV & $\begin{array}{l}\text { III.10.2 } \\
\text { III.10.4 }\end{array}$ & $\begin{array}{l}\text { VII } \\
\text { VII }\end{array}$ \\
\hline 6 & explains the importance of movement ... & V.10 & IV & $\begin{array}{l}\text { III.3.4 } \\
\text { III. } 3.5\end{array}$ & $\begin{array}{l}\text { VII } \\
\text { VII }\end{array}$ \\
\hline 7 & gives examples of proper leisure time ... & V.1 & IV & - & - \\
\hline 8 & describes the rules of first aid ... & V.5 & IV & - & - \\
\hline 9 & $\begin{array}{l}\text { gives examples of behaviours and situations } \\
\text { that may endanger human health and life ... }\end{array}$ & - & - & - & - \\
\hline 10 & $\begin{array}{l}\text { explains the meaning of symbols placed on e.g. } \\
\text { packaging ... }\end{array}$ & V.4 & IV & - & - \\
\hline 11 & $\begin{array}{l}\text { lists the basic principles of safe behaviour at } \\
\text { home... }\end{array}$ & - & - & - & - \\
\hline 12 & $\begin{array}{l}\text { explains the negative impact of alcohol, nico- } \\
\text { tine ... }\end{array}$ & V.8 & IV & $\begin{array}{l}\text { III.9.6 } \\
\text { V.10 }\end{array}$ & $\begin{array}{l}\text { VII } \\
\text { VIII }\end{array}$ \\
\hline 13 & lists the principles of a healthy lifestyle ... & V.10 & IV & $\begin{array}{l}\text { III.3.4 } \\
\text { III.4.7 } \\
\text { III.5.6 }\end{array}$ & $\begin{array}{l}\text { VII } \\
\text { VII } \\
\text { VII }\end{array}$ \\
\hline \multicolumn{6}{|c|}{ 10. Electrical and magnetic phenomena in science. Student: } \\
\hline 4 & $\begin{array}{l}\text {... describes and applies the principles of safe } \\
\text { handling of electrical equipment; }\end{array}$ & - & - & - & - \\
\hline
\end{tabular}

Table 3. Current science curriculum (grades 4-6) and the upcoming curriculum for science (4) and biology (5-8) - comparison. Indications: CC - core curriculum, "-" - no corresponding entry in the upcoming program for biology and science courses in elementary school. 
- And skills are defined as the ability to perform tasks and solve problems specific to a learning field or an occupational activity.

The aforementioned study assumes that health behaviours are a derivative of health consciousness, although this is not always the case. Consciousness corresponds to responsibility for one's behaviour (Puchalski, 1994, Słońska 1994). Taking this fact into consideration it was stated that, the school (and also didactic textbooks and other aids) should influence pupils' emotions in the process of shaping their health knowledge. Otherwise, their behaviour will most likely not reflect either their knowledge or skills.

Ratajczak explains that health awareness is a cognitive structure that directs and organizes people's health-related activities. According to Woynarowska, health consciousness depends on three components (Woynarowska, 2017): (1) structures that perceive signals of health hazards, (2) health and disease knowledge, derived from various sources, [in particular obtained ...] as an effect of one's own experiences with the consequences of health choices, and (3) health's place in the one's value hierarchy.

According to the premise of this study, the student's health awareness should be expressed by the student's analysis of problematic situations that are described in the subject textbook. Awareness should also be a reflection the student's personal experience (according to the fragment of Woynarowska's definition quoted above). Through such deliberations, a student can gain both the knowledge and the ability to make choices conducive to his or her health improvement and the value of such choices.

\section{Purpose and objectives of the study, research questions}

The main objectives of the study were:

- examining the content of science textbooks for grades 4-6 (in accordance with the current curriculum), with particular emphasis on the development of practical skills for implementing health knowledge. The above refers to the $3 \mathrm{rd}^{4}$ and $5 \mathrm{th}^{5}$ objective of educational curriculum in science for the second stage of education.

- assess whether the layout and content of the textbooks refer to aspects of the students' health consciousness - whether they relate to their emotions and prior experience.

Basic research questions corresponding to the objectives:

How much does the content of the reviewed textbooks correspond with the current curriculum?

Has the content of the textbook been extended from the objectives detailed in the current curriculum? If so, which contents were extended?

What health skills help shape the science textbooks?

Do the ways of presenting content related to health education affect the development of a students' awareness or, above all, the broadening of their knowledge in this field?

4 3rd Objective of education: Practical use of natural science knowledge. The student is aware of the surrounding nature and knowledge. The student is aware of the surrounding nature and
culture; recognizes health and life-threatening situations and undertakes actions to increase their own and other's safety, conscious$l y$ works to protect one's health.

5 5th Objective of education: Observations, measurements and experiences. The student uses various sources of information (own periences. The student un graphs, films), performs measurements and uses instructions (verbal, written and graphic); documents and presents the results of observations and experiences; uses information and communication technologies.

\section{Materials and methods}

The study was constructed analogously to the study described in the monograph Handbook of Life Sciences in the XXI Century, edited by Piotr Bieńka, in the chapter: The scope of health education in textbooks for the $\mathrm{Na}$ ture courses (Chrzanowski, Gawrońska, Aszklar, Piszczek, 2016). The methodology used is briefly described below ${ }^{6}$.

The initial phase of the study involved the preparation of a research tool (a large Excel spreadsheet) in the form of an external category grid that was searched for during the textbook analysis. The grid was created after analysing the curriculum of general education for the science course in the second stage of education and then distinguishing the content concerning health education. The list of entries is shown in Table 1.

There are no records of how (by what means) the contents of the curriculum should be implemented into the textbooks. To distinguish the main ways of presenting information in textbooks, a pilot analysis of randomly selected two textbooks was conducted. In addition, the tools used in another textbook evaluation for chemistry in middle schools were analysed. (Musialik, Chrzanowski, Buczek, Arèvalo-Garcia and Ostrowska, 2013) Based on the above analysis, two categories of elements were identified to be assessed:

- form of presentation (graphic or text) and

- the function that the tested item has to fulfil (Figure 1).

The conducted analysis of textbooks was both quantitative and qualitative, as shown in Figure 2 (Pingel, 2009). Quantitative analysis can be used to quantify how much emphasis is placed in these textbooks on

$\overline{6}$ Text based on a chapter in a monograph: Handbook of Life Sciences in the XXI Century: The scope of health education in textbooks for the Nature courses (Chrzanowski, Gawrońska, Aszklar, Piszczek, 2016). 
a particular topic. The quantitative measurement has also shown how often a given topic was discussed in the textbooks and the physical amount of space that was used in to describe the problem. The qualitative analysis was performed in order to supplement the analysis with a slightly more subjective interpretation and evaluation of the analysed elements. In this case, the study assessed what the graphics (text, etc.) say, how it's done, what information is conveyed, and what emotion it represents.
All analysed textbooks can be found on the list of school-approved textbooks for general education, based in the new core curriculum for pre-school education and general education for specific types of schools (List of school-approved textbooks, MEN, 2016). The list of analysed textbooks is presented in Table 4 . The textbooks from the Przyroda. Odkrywamy na nowo series (Wydawnictwo Pedagogiczne, OPERON Sp. z o.o.) are not available on the market. Therefore, the results of the study do not take their impact on teaching-learning categories included in the research questions. The study did not include didactic aids for the given textbooks.

It should also be noted here that the analysis performed was not intended to create rankings or to evaluate textbooks. It was only intended to interpret what elements of textbooks can influence the development of pupils' competences.
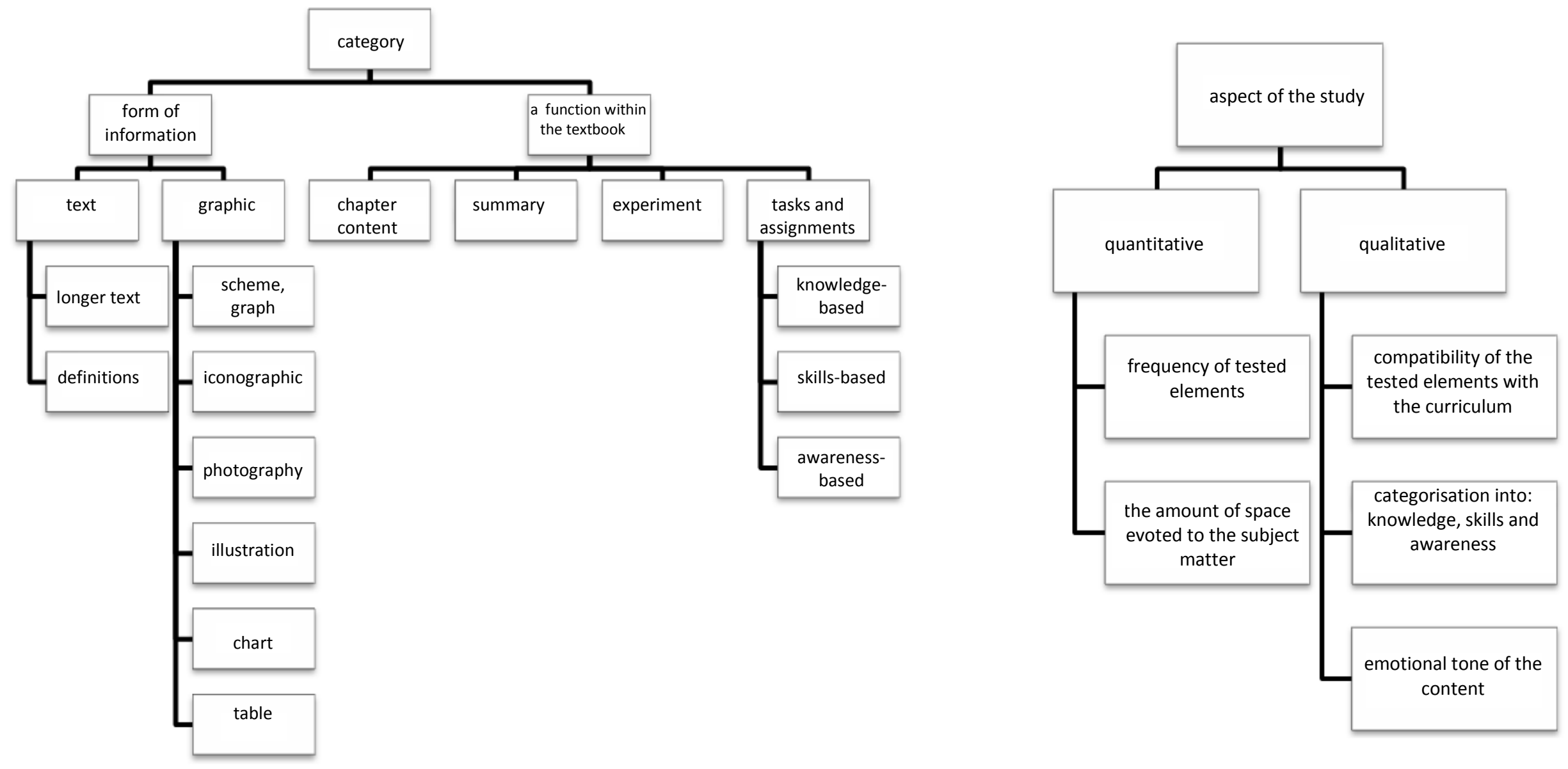

Figure 1: Categories of elements analysed in the studied textbooks Based on (Chrzanowski, Gawrońska, Aszklar, Piszczek, 2016).

Figure 2: Graphic representation of aspects used in the textbooks assessment Based on (Chrzanowski, Gawrońska, Aszklar, Piszczek, 2016). 


\begin{tabular}{|c|c|c|c|c|c|}
\hline series title & No. & $\begin{array}{l}\text { abrevia- } \\
\text { tion }\end{array}$ & textbook's title & textbook's author & editor \\
\hline \multirow{3}{*}{$\begin{array}{l}\text { Przyroda-poznać } \\
\text { i zrozumieć }\end{array}$} & 1.1 & Wiking 4 & $\begin{array}{l}\text { Przyroda - podręcznik dla klasy czwartej szkoły podsta- } \\
\text { wowej }\end{array}$ & Brygida Baranowska, Elżbieta Szedzianis, Robert Wers, Romana Woźnik & \multirow{3}{*}{ Wiking } \\
\hline & 1.2 & Wiking 5 & Przyroda. Podręcznik dla klasy piątej szkoły podstawowej & Brygida Baranowska, Elżbieta Szedzianis, Robert Wers, Romana Woźnik & \\
\hline & 1.3 & Wiking 6 & Przyroda - podręcznik dla klasy szóstej szkoły podstawowej & Brygida Baranowska, Elżbieta Szedzianis, Robert Wers, Romana Woźnik & \\
\hline \multirow{3}{*}{$\begin{array}{l}\text { Tajemnice przy- } \\
\text { rody }\end{array}$} & 2.1 & NE 4 & Tajemnice przyrody. Podręcznik dla klasy 4 & Maria Marko-Worłowska, Feliks Szlajfer, Joanna Stawarz & \multirow{3}{*}{ Nowa Era 1} \\
\hline & 2.2 & NE 5 & $\begin{array}{l}\text { Tajemnice przyrody } 5 \text {. Podręcznik dla klasy } 5 \text { szkoły podsta- } \\
\text { wowej }\end{array}$ & Janina Ślosarczyk, Ryszard Kozik, Feliks Szlajfer & \\
\hline & 2.3 & NE 6 & Tajemnice przyrody. Podręcznik dla klasy 6 & Joanna Stawarz, Feliks Szlajfer, Hanna Kowalczyk & \\
\hline \multirow{3}{*}{$\begin{array}{l}\text { Przyroda. Ciekawi } \\
\text { świata }\end{array}$} & 3.1 & OP 4 & Przyroda 4. Podręcznik dla szkoły podstawowej & Małgorzata Augustowska, Małgorzata Gajewska & \multirow{3}{*}{ OPERON } \\
\hline & 3.2 & OP 5 & Przyroda 5. Podręcznik dla szkoły podstawowej & Małgorzata Augustowska, Elżbieta Bytniewska, Małgorzata Gajewska, Marzena Karwowska & \\
\hline & 3.3 & OP 6 & Przyroda 6. Podręcznik dla szkoły podstawowej & Małgorzata Augustowska, Elżbieta Bytniewska, Małgorzata Gajewska, Marzena Karwowska & \\
\hline \multirow{3}{*}{ Przyroda z klasą } & 4.1 & Klett 4 & Przyroda z klasą. Podręcznik dla klasy 4 szkoły podstawowej & Joanna Buniowska, Ewa Frąckowiak, Ewa Gęca, Przemysław Jeruszka & \multirow{3}{*}{ LektorKlett } \\
\hline & 4.2 & Klett 5 & Przyroda z klasą. Podręcznik do klasy 5 & Joanna Buniowska, Ewa Frąckowiak, Ewa Gęca & \\
\hline & 4.3 & Klett 6 & Przyroda z klasą. Podręcznik do klasy 6 & Joanna Buniowska, Ewa Frąckowiak, Ewa Gęca & \\
\hline \multirow{3}{*}{ Przyrodo, witaj! } & 5.1 & WSiP 4 & Przyrodo, witaj! Podręcznik dla klasy 4 szkoły podstawowej & Ewa Gromek, Ewa Kłos, Wawrzyniec Kofta, Ewa Laskowska, Andrzej Melson & \multirow{3}{*}{ WSiP 1} \\
\hline & 5.2 & WSiP 5 & Przyrodo, witaj! Podręcznik dla klasy 5 szkoły podstawowej & Ewa Gromek, Ewa Kłos, Wawrzyniec Kofta, Ewa Laskowska, Andrzej Melson & \\
\hline & 5.3 & WSiP 6 & Przyrodo, witaj! Podręcznik dla klasy 6 szkoły podstawowej & Ewa Gromek, Ewa Kłos, Wawrzyniec Kofta, Ewa Laskowska, Andrzej Melson & \\
\hline \multirow{3}{*}{$\begin{array}{l}\text { Na tropach przy- } \\
\text { rody }\end{array}$} & 6.1 & Era 4 & Na tropach przyrody. Podręcznik dla klasy 4 & Marcin Braun, Wojciech Grajkowski, Marek Więckowski & \multirow{3}{*}{ Nowa Era 2} \\
\hline & 6.2 & Era 5 & Na tropach przyrody. Podręcznik dla klasy 5 & Marcin Braun, Wojciech Grajkowski, Marek Więckowski & \\
\hline & 6.3 & Era 6 & Na tropach przyrody. Podręcznik dla klasy 6 & Marcin Braun, Wojciech Grajkowski, Marek Więckowski & \\
\hline \multirow{3}{*}{$\begin{array}{l}\text { Przyroda w szkole } \\
\text { podstawowej }\end{array}$} & 7.1 & Żak 4 & $\begin{array}{l}\text { Przyroda 4. Podręcznik dla uczniów klasy } 4 \text { szkoły podsta- } \\
\text { wowej }\end{array}$ & Barbara Klimuszko, Janina Sokołowska, Maria M. Wilczyńska-Wołoszyn & \multirow{3}{*}{ Żak } \\
\hline & 7.2 & Żak 5 & $\begin{array}{l}\text { Przyroda 5. Podręcznik dla uczniów klasy } 5 \text { szkoły podsta- } \\
\text { wowej }\end{array}$ & Berenika Targos-Panak, Maria M. Wilczyńska-Wołoszyn & \\
\hline & 7.3 & Żak 6 & $\begin{array}{l}\text { Przyroda 6. Podręcznik dla uczniów klasy } 6 \text { szkoły podsta- } \\
\text { wowej }\end{array}$ & Leszek Bober, Berenika Targos-Panak, Maria M. Wilczyńska-Wołoszyn & \\
\hline \multirow[t]{3}{*}{$A B C$ przyrody } & 8.1 & $\mathrm{ABC} 4$ & Przyroda. Podręcznik dla 4 klasy szkoły podstawowej & $\begin{array}{l}\text { Barbara Gulewicz, Beata Brzozowska-Michałek, Anna Lauda-Michalska, Joanna Piętka- } \\
\text { Baumgart, Beata Ziółkowska }\end{array}$ & \multirow{3}{*}{$A B C$} \\
\hline & 8.2 & $\mathrm{ABC} 5$ & Przyroda. Podręcznik dla klasy 5 szkoły podstawowej & Barbara Gulewicz, Anna Lauda-Michalska, Joanna Piętka-Baumgart, Beata Ziółkowska & \\
\hline & 8.3 & $\mathrm{ABC} 6$ & Przyroda. Podręcznik dla 6 klasy szkoły podstawowej & Barbara Gulewicz, Anna Lauda-Michalska, Joanna Piętka-Baumgart, Beata Ziółkowska & \\
\hline \multirow{3}{*}{$\begin{array}{l}\text { Przyroda } \\
\text { z pomysłem }\end{array}$} & 9.1 & $\begin{array}{l}\text { WSiP } 4 \\
\text { PzP }\end{array}$ & $\begin{array}{l}\text { Przyroda z pomysłem. Część } 1 \text { i } 2 \text {. Podręcznik dla klasy } 4 \\
\text { szkoły podstawowej }\end{array}$ & Urszula Depczyk, Bożena Sienkiewicz, Halina Binkiewicz & \multirow{3}{*}{ WSiP 2} \\
\hline & 9.2 & $\begin{array}{l}\text { WSiP } 5 \\
\text { PzP }\end{array}$ & $\begin{array}{l}\text { Przyroda z pomysłem. Część } 1 \text { i } 2 \text {. Podręcznik dla klasy } 5 \\
\text { szkoły podstawowej }\end{array}$ & Urszula Depczyk, Bożena Sienkiewicz, Halina Binkiewicz & \\
\hline & 9.3 & $\begin{array}{l}\text { WSiP } 6 \\
\text { PzP }\end{array}$ & $\begin{array}{l}\text { Przyroda z pomysłem. Część } 1 \text { i } 2 \text {. Podręcznik dla klasy } 6 \\
\text { szkoły podstawowej. }\end{array}$ & Urszula Depczyk, Bożena Sienkiewicz, Halina Binkiewicz & \\
\hline
\end{tabular}

Table 4: List of analyzed textbooks

Abbreviation description: Wiking - Wiking "Wydawnictwo Edukacyjne" Wiking "Sp. j., Nowa Era - Nowa Era Spółka z o.o., OPERON - Wydawnictwo Pedagogiczne OPERON Sp. z o.o., WSiP - Wydawnictwa Szkolne

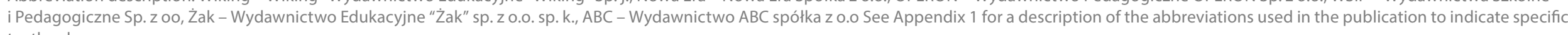
textbooks. 


\section{Results and discussion}

In view of the a wide range of the analysed materials, a review it conducted, that included a possible influence of textbooks on shaping children's and young people's health awareness using selected specific learning objectives included in the core curriculum (for the science course in the second educational stage):

1. Me and my surroundings,

5. Man and environment and

10. Electrical and magnetic phenomena in science ${ }^{7}$.

Individual sections are described separately as divided by subsequent textbooks for grades 4-6 and consecutive (semantically consistent) fragments of individual content records.

\section{Section 1. Me and my surroundings}

1.1. Lists positive and negative influences on his or her well-being at school and at home $(. . .)^{8}$

In the Era 4 textbook, the issue of well-being at school has been presented in a form of a short story. The authors highlighted the importance of pupils' correct relationship with their peers and teachers and positive learning results on their well-being in school. The influence of health and interests on their well-being at home or at school was not covered by the book. In addition, the problem of pupil's well-being at home has not been addressed in the textbook at all. In the questions under a chapter, students receive examples of problem solving situations that pose as a test of their ability to maintain their well-being at school. The authors of WSiP $4 \mathrm{PzP}$

7 Section 9 Health and health care analysis can be found in publications by Chrzanowski's and co-authors (Chrzanowski, Gawrońska, Aszklar, Piszczek, 2016).

8 The following textbooks do not cover these topics: Klett 4, Wiking 4, Żak 5, ABC 5, Klett 5, Op 5, WSiP 5, Era 5, WSiP 5 I PzP, WSiP 5 II PzP, Wiking 5, Op 6, Wiking 6, Klett 6, ABC 6, Żak 6, WSiP 6 PzP, WSiP 6, NE 6. textbook listed eight factors that cause the student's malaise at school. The chapter in which the subject is discussed is entitled "Well-being at school and at home", however, no reference to the determinants of the wellbeing of the student at home not any definitions of the term well-being was found. Domestic trouble was however mentioned among the factors that cause student's bad mood in school. The authors did not bring this issue closer in the text. The questions under this chapter are designed to test the student's ability to master the content presented during the discussion. Unfortunately, students do not find questions that involve their emotions or that improve their ability to speak about their own feelings within this textbook. The authors of the ABC 4 textbook listed the following factors that affect the well-being of a student at school: physical activity, leisure, healthy eating and sleep. The importance of relationships was only mentioned by the authors within one sentence. Most of the questions listed below are related to the student's knowledge. The questions completely ignore the importance of emotions and relationships with other people (peers, teachers, parents and siblings) for the well-being of children at school and at home. No questions that shape the student's health consciousness were found either. The authors of Op 4 textbook describe seven situations that affect student's wellbeing of at school. They mention the principles of social coexistence that allow us to shape relationships with other people. With the help of the photos, they teach the proper recognition of emotions that other people can feel, thereby contributing to the development of empathy in the pupils. The authors of Żak 4 textbook list several factors that influence people's well-being. The text on this subject is very concise, but the questions under the chapter encourage the students to reflect on their own feelings about the school and its environment. The authors of WSiP 4 textbook discuss several important factors that shape the well-being of a student at school. They also provide some good advice on how to behave in order to be popular among peers. They also raise the issue of shyness. The questions under this chapter are designed to test the students' knowledge, skills and develop their health awareness. The authors did not mention the issue of students' well-being at home.

\section{(...) suggests ways of eliminating negative factors ${ }^{9}$}

The authors of the Era 4 textbook have presented a short story suggesting several ways to eliminate negative factors to improve children's well-being at school. Based on the story, students can come to the conclusion that the ability to ask their teachers or colleagues for help can help overcome learning difficulties. In the story, important factors that affect the students' wellbeing are missing: health, interesting leisure time, positive attitudes towards oneself and the environment. The WSiP 4 PzP textbook lists a number of ways to effectively improve students' well-being at school and at home. It is important for the students to know where they can seek help in difficult situations that they cannot handle by themselves. The authors have mentioned a nationwide telephone number, which the student can use in extremely difficult situations. There is a very valuable message for students implying that their well-being depends to a great extent on their behaviour. The illustrated guide includes a number of practical tips on how to improve one's well-being which can be used by a student in their everyday lives. The textbook doesn't include questions directed at a student regarding their own effective ways to improve their mood. Unfortunately, the only question related to the subject asks to re-

9 The following textbooks do not cover these topics: Klett 4, Wiking 4, Żak 5, ABC 5, Klett 5, Op 5, WSiP 5, Era 5, WSiP 5 I PzP, WSiP 5 II PzP, Wiking 5, Op 6, Wiking 6, Klett 6, ABC 6, Żak 6, WSiP 6 PzP, WSiP 6, NE 6. 
produce the information contained in the text. The $\mathrm{ABC}$ 4 textbook focuses on the physiological factors that influence the student's well-being at home and school. Therefore, the listed means to eliminate negative factors are related to physical activity, rest, healthy eating, and sufficient sleep. The authors did not mention any interesting forms of spending free time, developing interests, building positive relationships with their peers at school or the rules of proper communication with teachers and parents. The importance of emotion and mental health for the well-being of children has therefore been omitted. In the Op 4 textbook, the students find suggestions for behaviours and activities that can improve the atmosphere in their family home. They also learn what situations should be avoided to make sure their relationships with peers are as good as possible. Among the assignments under the chapter, the authors placed a task in which they encouraged students to consider ways to help a fellow student who is confused and experiences learning difficulties. In addition, the next task asks to present their own ideas to improve the well-being of their families. Both tasks aim to develop students' empathy towards other people. The authors of the Żak 4 textbook appreciate the importance of science contact in everyday well-being. In the exercise no. 3 on page 17, students have an opportunity to propose their own ways of eliminating adversities that affect their well-being at school and at home. The authors of the WSiP 4 textbook provide examples of behaviours that can improve the schoolchildren's well-being. They provide ways to gain sympathy from their peers, but also focus on the problems of shy and disabled people. The questions under the chapter test students' knowledge and skills, but also develop their health awareness.
1.2. explains the importance of rest (including sleep), nutrition and physical activity in the proper functioning of the body $y^{10}$

The WSiP 4 PzP textbook describes the importance of proper nutrition, physical activity, rest, including sleep for human health. Using the illustration, the authors presented examples of the correct and incorrect school lunches. The textbook does not mention any information concerning the fact that an inadequate diet containing large amounts of sweets, salty and fatty snacks and fast foods, often leads to childhood obesity, which can cause serious adult illnesses. Discussing the importance of physical activity for the body, the authors also did not expand on the problem of obesity, which is becoming more and more common in the society. Most of the questions under this chapter are designed to test the student's knowledge gained from the text. One of them relates to the influence of students' physical activity on their health and contributes to the development of health consciousness. The authors of the ABC 4 textbook focused primarily on discussing the principles of healthy eating and their importance to young person's health and well-being. The book contains a food pyramid and a sample menu for the primary school pupil. In addition, so-called organic products were mentioned to play a role in proper nutrition. The exercise listed under a chapter instructing the student to plan a healthy meal, e.g. a school lunch, is very important for the students' ability to develop their skills and health-consciousness. A separate chapter was devoted to the topic of healthy eating, while the importance of sleep, various forms of active and passive rest was discussed in a rather lapidary way. The authors of the Op 4 textbook described the importance of sleep, rest and physical activity for the proper functioning of the body in the chapter titled: "The body needs to be taken care of". Using the

10 The following textbooks do not cover these topics: Klett 4, WSiP 4 , Op 6, Wiking 6, Klett 6, ABC 6, NE 6. graph, they presented a student's daily activity cycle. In this chapter, a student can find tasks that allow him or her to develop the ability to analyse data contained in charts and tables and to draw conclusions. In addition, the instruction to develop a leaflet encouraging physical activity for students and their parents can help shape health awareness. The importance of proper nutrition for human health is described in a separate chapter entitled "Healthy eating prevents illnesses." The authors offered examples of products that a student can eat for breakfast and lunch. While planning their diet students can use the pyramid provided in the textbook. They also have the opportunity to review the rules of healthy eating, as well as practice their calorie intake with sweet snacks. In the Żak 4 textbook, students find information related to the meaning of rest and physical exercises for everyday strength regeneration. The authors have included a question addressed to the students regarding their behaviour, which would prevent them from being tired. Two illustrations also remind students of the need to rest. Unfortunately, there are no questions about the topic. Moreover, the authors skipped important topics of healthy eating, which are necessary for proper functioning of the body.

In the $\mathrm{ABC} 5$ textbook the issue is presented in two separate sections: in section 3. - "Human organism" and section 4. - "Health and heath care". They focus mostly on the importance of proper diet in the proper functioning of the body. This topic is covered in both of the above-mentioned sections of the textbook. They point to the need for a balanced diet in everyday life. The term "balanced diet" has been introduced and defined in Chapter 3. In the next health section, pupils are given a task to observe their diet to determine if it's balanced. The authors also suggested to perform a comparison exercise of the composition of three carrot juices with different expiration dates to determine 
their suitability for consumption. The element of observation in the teaching process used by the authors of the ABC 5 textbook, can contribute to the students' health awareness development while discussing issues related to the importance of nutrition for the proper functioning of the human body. Unfortunately, the importance of physical activity and rest in human health is much less exposed in this textbook. Any tasks aimed at health awareness improvement in this topic are also missing. In addition, the authors completely ignored the role of sleep in the proper functioning of the body. The Klett 5 textbook describes in detail the role of individual nutrients in the human body and the importance of physical activity and sufficient sleep for the health and well-being of all systems and organs. The authors place too little weight on shaping and developing the students' health awareness. Therefore it lacks instructions and questions that directly address their dietary preferences, as well as their most common physical activities. In the Op 5 textbook, the authors describe the importance of proper nutrition, physical activity and rest for human health in quite great detail. These contents are discussed in two sections: in section 3. "Human organism" and in section 4. "Health and health care". The authors introduced an experiment to the educational process recommending the students to examine their pulse before and after exercise. The WSiP 5 textbook provides information on the role of individual nutrients in the human body and the importance of physical activity for overall fitness. It was also stressed that adequate sleep is needed for proper functioning of the body. This book provides tips on how to ensure a healthy sleep. The tasks addressed to pupils do not, however, develop their health consciousness. In the Era 5 textbook, the authors describe the importance of eating for the proper functioning of the human body, but completely overlook the role of rest (including sleep). They recommended sports and active games for the proper functioning of muscles and bones. The topic of nutrition is described in two chapters: "Why do we eat and drink?" and "How to eat healthy?" In order to make students aware of the importance of proper nutrition for human health, the authors used two graphics. The first one on page 136 illustrates two basic functions of food, and the other, on page 139 shows different types of foods and their function in the body and how much they should be consumed. The second one of these serves as a food pyramid and can be used by students to plan their own diet. The WSiP 5 II PzP textbook explains the role of particular nutrients in the functioning of the organism and, what's important, the negative effects of improper nutrition on the health and well-being of humans. It also explains why physical activity is a prerequisite for maintaining good health. It was emphasized that regular sport activities and exercise affect the proper functioning of the blood and respiratory system. In order to prove the importance of physical activity for the functioning of the circulatory system, an experiment entitled "Does physical activity affect heart rate?" was introduced. The role of sleep and rest in maintaining health was also mentioned. The Wiking 5 textbook explains the importance of physical activity and proper nutrition for the human body. Least focus was allocated to describe the meaning of sleep and rest for human health. It was only mentioned that wellplanned rest and adequate sleep strengthens the body's immune system and helps to prevent infectious diseases. In order to develop the student's health consciousness, the authors placed questions about the benefits that students derive from their sports discipline. There was also an important task to convince your peers to sign up for the School Sports Club.

The authors of the Żak 6 textbook, used a graph to illustrate the energy needs of humans in terms of age while discussing the importance of proper nutrition for the proper functioning of the body. This gives the 6th grade student an opportunity to gain valuable skills in analysing charts. Unfortunately, the questions under the chapter do not address the problem. The importance of physical activity and rest for the human body has been extensively discussed in the text. Also, in the questions under this chapter, the authors referred to this issue by examining the students' knowledge as well as their ability to formulate conclusions. In part II of the WSiP 6 PzP textbook, in section: "Knowledge recap before middle school", the authors mentioned the role of nutrients for the proper functioning of the human body and introduced a food pyramid. Issues related to the importance of rest and physical activity were not mentioned by the authors. There are no questions to assess the students' knowledge and skills. The authors of the section titled: "Knowledge recap - how to be healthy?" in the WSiP 6 textbook reminded the students of the four basic principles of healthy eating and proper ways of spending free time. They missed the importance of sleep for the proper functioning of the body. The questions under the chapter refer only to the ways of spending free time and the importance of physical active for health.

\subsection{Lists the principles of correct learning (.... $)^{n}$}

Students, who use the Wiking 4 textbook learn the correct learning principles. They learn about the necessity of solidifying knowledge by regular repetition. The authors also emphasize that the effectiveness of learning is also influenced by systematic, daily homework done at the same time every day, starting with the most difficult task and taking short breaks in learning. The authors concisely warn against doing homework too late in the

11 The following textbooks do not cover these topics: Żak 5, ABC 5, Klett 5, Op 5, WSiP 5, Era 5, WSiP 5 I PzP , WSiP 5 II PzP, Wiking 5, Op 6, Wiking 6, Klett 6, ABC 6, Żak 6, WSiP 6 PzP , WSiP 6, NE 6. 
evening. However, they do not explain why it is not advisable to do homework too late. This textbook contains an illustration that encourages the students to clarify what factors distract them from doing homework. The authors of the Era 4 textbook have listed and widely described the five principles of effective learning. The text has been completed with a photo encouraging students to visit interesting places such as the zoo and with drawings that can inspire pupils to develop their own effective learning methods. At the end of this chapter, the authors provided a short poem, suggesting that the conditions and the place are very important in learning. At the end of the chapter there is a question about the student's knowledge of the principles of effective learning. The authors of the WSiP 4 PzP textbook have listed six principles of good learning. They also drew attention to several factors related to conditions and student attitudes that may help or hinder the learning process. The authors have included a sample mind map about science, but they have not explained in the text that creating a variety of schemes is a good way to understand and memorize the curriculum content. The question related to the learning principles presented under the chapter is reproductive. The authors of the ABC 4 textbook have listed three principles of correct learning. They pointed out that learning begins in the classroom, and included some important advice on how to make the most out of the lesson time so that you could effectively master the issues discussed. They also stressed the importance of frequent knowledge repetition and the use of appropriate learning techniques that differ between visualizers, audiles and kinaesthetic. The questions at the end of this chapter check students' knowledge and skills in the subject matter discussed. The authors of the Op 4 textbook list and briefly describe three principles of proper learning. They drew attention to systematic learning, concentration and well-utilized lesson time, as well as tests preparation. Students who use the textbook can also offer fellow students ways to improve their learning. In addition, the last task listed under the chapter commanding students to talk about school success, that gave them the most joy, allows them to share their emotions with others. In the Żak 4 textbook, the principles of correct learning have been described by the authors in a uniform text. There are no bullet points to help students learn. Interwoven questions related to the students' learning conditions encourage them to reflect and draw conclusions. The authors of the Klett 4 textbook briefly discuss the principles of proper learning. They highlighted the importance of rest, proper nutrition, learning breaks, and effective planning for effective learning. They skipped the importance of effective time utilisation during school lessons, attention, and frequent repetition of the content. Under the chapter we find one question related to these issues, which is reproductive. The authors of the WSiP 4 textbook have listed seven principles of good learning. They emphasized the importance of systematism for achieving positive results in science. You will also find the characteristics of a good student, as well as the possible causes for learning difficulties. The questions under the chapter tests the students' knowledge related to the problem and their ability to analyse and draw conclusions.

\subsection{Applies the rules of proper learning in life ${ }^{12}$}

The authors of the Wiking 4 textbook while discussing the principles of correct learning, have put questions addressed to the student regarding his or her learning principles, and the factors that help or distract them during studying. The authors of the Era 4 textbook have proposed two simple practical exercises that consist

12 The following textbooks do not cover these topics: Żak 5, ABC 5,
Klett 5, Op 5, WSiP 5, Era 5, WSiP 5 I PzP, WSiP 5 II PzP, Wiking 5, Op 6, Wiking 6, Klett 6, ABC 6, Żak 6, WSiP 6 PzP, WSiP 6, NE. in comparing the effectiveness of word memorization. In the first exercise, students read the words given in the textbook, then write down those they memorized. In the second one, they read words that are associated with objects in their surroundings, and then also write the ones they remembered. In the final stage, the student compares the number of words recorded in both exercises and draws conclusions. A student who uses the textbook can also use a diagram to present the contents of the frame on page 160 in the exercise at the end of the chapter. Apart from the aforementioned practical exercises and tasks to check the student's ability to visualize the content, a question regarding the methods students use in their daily life, preparing for their tests is missing. The WSiP 4 PzP textbook does not offer any practical exercises to teach students how to apply the principles of correct learning. On the other hand, while discussing the issues, authors devoted a great deal of attention to the student's attitude, including motivations and concentration abilities, which could therefore be an important element of the training, demonstrating ways of eliminating factors that have a negative impact. In the $\mathrm{ABC} 4$ textbook, the authors have not proposed any practical exercises that would test and improve the students' proper learning skills. The question no. 7 on page 22 should unambiguously address the most effective learning methods used by the student. The authors of the Op 4 textbook present a table with questions that prompt students to think about diligently pursuing school duties. Moreover, they stress the importance of motivation in task performance success. The question at the end of the chapter prompts the students to reflect on the factors that help or interfere with the school work. The authors of the Żak 4 textbook recommend that students evaluate their learning style and conditions. The Klett 4 textbook does not reference to the learning principles that students use. Students, who use the WSiP 4 
textbook cannot evaluate their learning effectiveness. The authors did not propose any tasks that would allow them to analyse their current learning methods nor did they propose any possible improvement methods.

\subsection{Describes a properly designed learning place for a primary school} pupir $^{13}$

The authors of the Wiking 4 textbook describe how to organize a learning place at home. They pay attention to the correct illumination of the place, maintaining order on the desk and frequent airing of the room. The authors also emphasize the importance of proper selection of furniture for doing homework. They recommend a simple practical exercise that is designed to make students aware of the need to choose a chair and table of the right height to maintain the correct body posture during the lesson. Under this chapter, the authors provide a task to check the student's knowledge on the subject. In the Era 4 textbook there is a picture with items described, showing the correct place to learn. It draws attention to a number of important issues such as fresh air supply, proper lighting, a chair and a table of appropriate height, order on the table and access to the computer. At the end of this chapter there is a question that addresses student's knowledge of the subject. Unfortunately, the authors did not encourage pupils to describe and evaluate their own learning places. The WSiP 4 PzP textbook describes five conditions that should be met by a properly designed learning place. In the diagram, an essential condition of fresh air access to the room in which the student is learning is omitted. The questions under this chapter refer to the contents of the textbook on the properly prepared learning

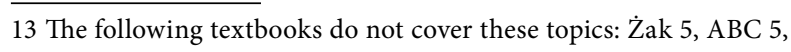
Klett 5, Op 5, WSiP 5, Era 5, WSiP 5 I PzP, WSiP 5 II PzP, Wiking 5, Op 6, Wiking 6, Klett 6, ABC 6, Żak 6, WSiP 6 PzP, WSiP 6, NE 6. place. However, there is no reference to the students' situations and to the evaluation of their own place of study. In the ABC 4 textbook, the authors emphasized the importance of accepting the right position while learning. They pointed out the effects of taking wrong positions for spinal defects in students who have improperly designed study places and neglect their motor activity. The authors have provided a picture that accurately illustrates the properly arranged place of work for the student. The questions under the chapter relate to the students' knowledge contained in the text but do not develop their planning skills and health awareness. The authors of the Op 4 textbook have described how to properly organize a learning space so that the conditions and atmosphere support concentration. The picture in the book does not show all of the items that you need to include in your place of work. Health awareness and critical assessment skills are developed by the students through an assignment of their own learning place. The authors of the Żak 4 textbook included two pictures on which they presented bad and good learning conditions. The student is to evaluate his or her working place and condition using photos. The authors of Klett 4 textbook have described how a properly designed learning place should look. They did not include any photos of the student's room, which would show what a room or a learning place should be. The picture shows only the correct attitude of the student while learning. A small illustration included in the textbook only highlights the importance of proper lighting in the workplace. The question underneath the text urges the student to evaluate his or her own learning place. The authors of the WSiP 4 textbook used an illustration with the described elements to present the correct and incorrect posture of the body and a correctly and incorrectly arranged learning place. They also mentioned factors that affect learning: proper room temperature, lighting and noise. Unfortunately, there was a shortage of tasks for the students, which would allow them to evaluate their own study places.

\section{Explains to the need to plan day and week activities (... $)^{14}$}

The authors of the Wiking 4 textbook explain the need to schedule day and week activities in a few sentences. There is, however, no clear message that planning all day-to-day activities dictates the proper management of time, so that it can also be used for the development of one's own interests or for passive and active rest. One question concerning students' knowledge related to the need for daytime scheduling is included in the chapter. The Era 4 textbook provides an explanation for planning your day and week activities, and using a calendar, where you can schedule important appointments and activities. The authors say that through planning, time can be used more effectively, which will allow the student to save it for rest, play, develop interests or for physical activity. The lack of planning can lead to wasted time, for example, while watching TV or computer games for too long. Therefore, authors in a rather original way remind the students to turn the computer on only for specific reasons. The questions under the chapter ask the student to relate to their knowledge and skills regarding the importance of sleep and rest for the health of the body. Authors of the WSiP 4 PzP textbook have written about the benefits of day-to-day planning. An important conclusion in the text is that planning has a positive influence on the lifestyle, which in turn promotes health. Hence, the authors have assigned a very important task to the students to assess their own way of spending free time, whether it is conducive to health and what can be changed for the better. The authors of

14 The following textbooks do not cover these topics: 5, ABC 5, Klett 5, Op 5, Era 5, WSiP 5 I PzP , WSiP 5 II PzP, Wiking 5, Op 6, Wiking 6, Klett 6, ABC 6, Żak 6, WSiP 6 PzP, WSiP 6, NE 6. 
the ABC 4 textbook signalled the necessity of activity planning during the day and week in two sentences. They emphasized that proper activity planning allows time for interest development, rest and various everyday activities. There is a very important question for the development of the student's health consciousness about the effects of inappropriate day planning for students' bodies. The authors of the Op 4 textbook devote considerable attention to the need for planning the day and week activities. They share the benefits of proper time management to help you achieve your goals, develop your interests, and find time to rest. The authors also try to convince students how important planning is when organizing trips or travels. The students can also find questions that develop their ability to plan and analyse their schedule, as well as their health awareness. The authors of the Zak 4 and Klett 4 textbooks do not provide reasons for the necessity of planning the day and week activities. The WSiP 4 textbook does not address this issue.

A student using the WSiP 5 textbook can use its content to justify the need for day-to-day planning. It is clear from the text that scheduling daily activities allows us to make use of our time effectively and to spend it developing interests and resting. The authors have published a questionnaire examining pupils' skills related to this problem.

\section{5. (...) correctly plans and executes his or her schedule during the day ${ }^{15}$}

In the Wiking 4 textbook, the authors provide a table showing the sample day schedule for a fourth grade primary school pupil. Students were asked to plan their work day, which is very important for the development of their skills and health awareness. Also, students who

15 The following textbooks do not cover these topics: Żak 5, ABC 5, Klett 5, Op 5, Era 5, WSiP 5 I PzP, WSiP 5 II PzP, Wiking 5, Op 6, Wiking 6, Klett 6, ABC 6, Żak 6, WSiP 6 PzP, WSiP 6, NE 6. use the book received the task to present interesting ideas for spending their free time. In the Era 4 textbook, students can read the instructions on how to prepare their day plan. Next to the instructions there is also a sample day plan. The authors did not limit themselves to explaining the day's activity planning, but also encouraged the students to create their weekly activity plans. A sample weekly plan is also included in the textbook. In the tasks addressed to the students at the end of the chapter, there is an assignment to create a day plan for tomorrow. The authors of WSiP 4 PzP explain how to plan a day to complete all school and home duties and find time for physical activity, fun, rest and sleep. An example of a day plan in the form of a diagram is included in the textbook, which can be helpful for the student when creating their own. The authors also provided students with suggestions for useful, healthoriented use of their leisure time. They warned young people of violent computer games and TV shows, and making acquaintances through the internet. The question under the chapter refers to the knowledge that is given to the student in the text. It would be helpful for gaining the practical planning and organizing skills if students received a task to arrange a day plan for themselves, which is unfortunately missing in the discussed textbook. The authors of the ABC 4 textbook included three basic principles of good learning organization and some practical tips on how to plan each day. The last two questions at the end of the chapter check the student's ability to plan and execute tasks. The authors of the Op 4 textbook gave out a sample lesson plan for a grade 4 student and posted a question that educates students about how to analyse and draw conclusions. Unfortunately, they did not offer students the task of planning their own activities, for example, for a random day of the week. A student who uses the Zak 4 textbook learns the rules of proper daytime planning. The authors did not, however, include in the textbook any sample activity schedules on which students could model their own. The pupil's ability to plan properly is to be determined by his or her own daily plan, based on the rules provided in the textbook. The authors of the Klett 4 textbook tell you what to look out for to properly plan your daily activities. The last two tasks under the chapter develop the student's practical skills in independently planning their day and the week activities. The authors of the WSiP 4 textbook skipped this issue.

The authors of the WSiP 5 textbook have included a sample 24-hour schedule to encourage students to draw up their own plan. The questions under the chapter do not, however, include such a command.

\section{6 (...) applies safety rules during natural observation ${ }^{16}$}

The authors of the Era 4 textbook briefly describe the basic safety principles that should be followed during experiments and science observation. They also referred to a situation when students plan the experiments themselves and pointed out the need to consult a teacher or a parent for safety reasons. At the end of the chapter, students will be asked to examine their knowledge of safety during experiments and natural observations. The authors of the WSiP $4 \mathrm{PzP}$ textbook mention safety concerns as a part of experimentation rules, especially when dealing with chemicals that may be harmful to health and doing experiments with fire. In the summary of the chapter and in the questions under the chapter there is no reference to this important content The authors of the ABC 4 textbook included a naturalist's code that consists of sixteen principles that should be followed by the students during field observations in

16 The following textbooks do not cover these topics: Wiking 4, Żak 5, ABC 5, Klett 5, Op 5, WSiP 5, Era 5, WSiP 5 I PzP , WSiP 5 II PzP, Wiking 5, Op 6, Wiking 6, Klett 6, ABC 6, Żak 6, WSiP 6 PzP, WSiP 6, NE 6 . 
order to preserve their safety and to not destroy the surrounding science. The questions under this chapter are missing any references to these issues. The authors of the Op 4 textbook have omitted the safety issues while describing the principles of natural observation. However, they pointed out that when we learn about science through our senses we do have to be careful - first of all not to sniff on the unknown substances and not to try unknown fruits and mushrooms that can be poisonous. Students do not find any questions under the chapter that would test their knowledge or skills related to this subject. The authors of Żak 4 textbook mention the necessity of maintaining safety while carrying out natural observations outside the school grounds. They emphasize the need for following traffic rules, paying special attention near rivers or lakes, avoiding creating obstacles to others, and following teacher's recommendations. The questions under this chapter do not reference this problem. In the Klett 4 textbook, a student finds notes that it is important to take care of their safety while conducting field observation both in the classroom and in the field. The questions under this chapter are designed to test the students' knowledge and skills. The authors of the WSiP 4 textbook mentioned the need to preserve safety while learning about science through taste and smell senses. These problems were further addressed in the second question, presented under the chapter on page 18.

1.9. recognizes and names some plants (including pots) containing substances that are poisonous or harmful to humans (... $)^{17}$

The authors of the Wiking 4 textbook have taken pictures of poisonous garden and potted plants to help students identify them. The text also mentions dan-

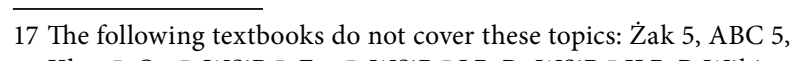
Klett 5, Op 5, WSiP 5, Era 5, WSiP 5 I PzP, WSiP 5 II PzP, Wiking 5, Op 6, Wiking 6, Klett 6, ABC 6, Żak 6, WSiP 6, NE 6. gerous meadow plants and provides pictures of them. Plants that contain narcotic substances used in medicine, that also cause very dangerous addictions that lead to the destruction of the body and death are also mentioned. The authors have included an assignment under the chapter that urges pupils to use sources of information other than the textbook (book about potted plants), to find out which of the potted plants in their house are poisonous. The authors of the Era 4 textbook provided six examples of poisonous plants growing in gardens and parks, three examples of poisonous weeds, and three examples of poisonous potted plants. They put photos of them in the textbook, which allows them to be identified. In the task at the end of the chapter, the authors placed a statement addressed to the students, referring to examples of poisonous plants growing in their environment. The WSiP 4 PzP textbook contains photos of three types of poisonous pot plants that can be found in pupils' homes. The text mentions that there are some plant species growing in parks, gardens, meadows and forests, which are also poisonous, but no photos or names are given within the textbook. It has been explained, however, that the poisonous effects of some plants are due to the juices they produce that are harmful to the body. The question for students, which is addressed under this chapter, tests the knowledge they acquired from the text. The authors did not mention the topic of poisonous plants in the summary of the section. In the $\mathrm{ABC} 4$ textbook a student finds eleven examples of poisonous plants. Thanks to the photos and some short characteristics of each species, it is easy to identify them in the field. The question under the chapter that deals with this topic is reproductive. A student using the Op 4 textbook learns how to handle plants that may contain harmful and even poisonous substances. Unfortunately, the authors did not include any examples of such plants in the textbook. The question under this chapter examines the student's knowledge of how to prevent poisoning while caring for home plants or plants growing under natural conditions. Authors of the Żak 4 textbook have listed examples of poisonous plants that occur in the wild, poisonous domestic plants and poisonous garden plants. They took three photos from each of these groups of plants. In addition, some of the examples of poisonous plants are listed in tables. Unfortunately, under the chapter there were no assignments that check the students' knowledge and skills associated with the curriculum. The Klett 4 textbook provides eight examples of poisonous plants: potted, growing in forests, parks and gardens. The pictures and short descriptions help students gain practical skills in recognizing them in the natural environment. The questions under the chapter are reproductive. The authors of the WSiP 4 textbook provided only two examples of pot plants that are harmful to humans. The photos of these plants allow students to gain the ability to identify them. The students' knowledge of the subject is tested through a question that prompts them to explain why some plants are dangerous to humans.

In the WSiP $6 \mathrm{PzP}$ (part II) textbook, in a chapter entitled „Knowledge recap before middle school”, it was recalled that fruits, seeds and flowers of some plants contain poisonous substances, which is why they should be handled with caution. Yew is given as an example.

1.9 (...) provides the rules for dealing with them (some plants, including potted plants, containing substances that are poisonous or harmful to humans. ${ }^{18}$

The Wiking 4 textbook lists two rules for dealing with poisonous plants. One of them says that such spec-

18 The following textbooks do not cover these topics: Żak 5, ABC 5, Klett 5, Op 5, WSiP 5, Era 5, WSiP 5 I PzP, WSiP 5 II PzP, Wiking 5, Op 6, Wiking 6, Klett 6, ABC 6, Żak 6, WSiP 6 PzP, WSiP 6, NE 6. 
imens should not be located in places that small children and pets have access to. The second one points to the necessity of using protective gloves when replanting and handling. There is no information that these plants should not be eaten and that you should wash your hands even after touching them accidentally. The text briefly describes the health consequences of their consumption. Importantly, recommendations are given as to what to do after a poisonous plant has been eaten. The manual also includes a warning about the milk juice produced by some dangerous plants growing in meadows and fields. In the questions addressed to pupils at the end of the chapter, there was no mention of rules for the poisonous plant treatment. In the Era 4 textbook there are three rules for dealing with poisonous plants growing in gardens and parks. There is no mention of any precautionary principles in the care of poisonous pot plants at home. The questions addressed to students refer to their knowledge in the subject. Authors of the WSiP 4 PzP textbook have informed students about the safety rules to be followed during poisonous pot plants treatment. They also advised caution during walks and advised to avoid direct contact with unknown plants that attract attention through their tasty-looking fruit, beautiful flowers or ornamental leaves. The authors of the textbook did not explain how to behave after consuming poisonous plants. They noted the problem of allergies, caused by some plants' pollen. The question addressed to students under the chapter test their knowledge acquired from the text. In the $\mathrm{ABC} 4$ textbook, a student is to become familiarized with the basic safety principles when encountering poisonous plants. They also learn what to do if one gets poisoned. The student's acquired knowledge is checked by the questions at the end of the chapter that are reproductive. The authors of the Op 4 textbook list four principles for dealing with potted plants and plants growing on meadows or in forests that may be poisonous. The question under this chapter examines the student's knowledge of how to prevent accidental poisoning while handling home plants or plant growing in the wild. Authors of the Żak 4 textbook also provide four principles for dealing with poisonous plants. However, there is no mention of safe handling practices for poisonous plants at home and for young children access limitations. Under the chapter there is one question that examines pupils' knowledge of proper handling of poisonous plants. In the Klett 4 textbook students find practical advice on how to properly cultivate poisonous potted plants. In addition, there is a very important warning against eating very tastylooking fruits of some poisonous plants. The questions under the chapter tests the students' knowledge and skills, and develops their health awareness. The authors of the WSiP 4 textbook talk about the principles of safety while in contact with poisonous potted plants that may be in the pupil's home. Under the chapter there is a question that examines their knowledge in this field. There are no questions that develop health awareness related to poisonous pot plants that a pupil may have in his home.

\section{Section 5. Man and the environment}

5.5 gives examples of positive and negative environmental impacts on human health $h^{19}$

The authors of the Wiking 4 textbook discuss the impact of climate factors and environmental pollutants on human health. They described how we can protect ourselves from the negative effects of climate factors on our health. The more serious problem that the authors have mentioned is the environment pollution resulting

19 The following textbooks do not cover these topics: Era 4, WSiP 4 PzP, Żak 5, ABC 5, Klett 5, Op 5, WSiP 5, Era 5, WSiP 5 I PzP Wiking 5, Op 6, Wiking 6, Klett 6, ABC 6, Żak 6, WSiP 6 PzP, WSiP 6, NE 6. from industry development, motorway construction and the use of fertilizers in agriculture. Unfortunately, the chapter does not address solutions to this problem, omitting, for example, the topic of organic farming. The textbook shows how the harmful substances get from the environment to the human body by using a scheme. The chapter includes questions about the student's knowledge and skills related to the topic. In the ABC 4 textbook, we can find some information about the negative impact harmful substances found in the environment have on human health. The authors also mention diseases that may be caused by coming in contact with them. The course book devotes a lot of attention to the negative impact of noise on human health, but the topic of the positive impact of science contact on our mental and physical health is omitted. The questions under the chapter are very general and reproductive. The authors of the Op 4 textbook list and briefly describe examples of environmental factors that have positive and negative effects on our health. Among the positive factors they highlight the importance of outdoor walks, spa visits, bathing in natural healing waters, staying in the sun, and proper nutrition. The student is also provided with some examples of the negative impact of polluted environment on human health. In addition, the authors mention the destructive impact of noise on human health. The questions listed below only test the student's knowledge. The authors of the Żak 4 textbook completely ignored all the aspects related to the positive impact the environment has on human health. On the other hand, they devoted much of their attention to the problem of human activity, which leads to pollution of the natural environment, which in turn causes many serious diseases. These diseases were not mentioned by the authors of the textbook. In the Klett 4 textbook, the topic of positive environmental impact on human health has been completely omitted. In the chapter 
devoted to the human activity's impact on the state of the natural environment we find only a brief mention of the dangerous effect of smog on human health and the relationship between the occurrence of ozone holes in the atmosphere and the increased development of skin cancer. There are no questions under the chapter or in the repetition section of the chapter about the issues related to the discussed topic. The authors of the WSiP 4 textbook explained what living in harmony with science means. They emphasized the importance of human contact with science and healthy eating. They also referred to the problem of so-called organic farming. Under the chapter, they ask questions that shape the students' health consciousness, prompting them to wonder if they live in harmony with science.

The WSiP 5 II PzP textbook mentions the negative impact of air, water and soil pollution on the human body. However, the positive impact of the contact with natural environment and science on mental and physical health has been neglected.

10. Electrical and magnetic phenomena in science

10.4 ... describes (...) the principles of safe handling of electrical appliances; (...) applies the principles of safe handling of electrical appliances ${ }^{20}$

The authors of the Era 4 textbook listed three safety rules that must be followed while handling household electrical appliances. There are no rules for removing a plug of the electric appliance with wet hands, as well as for the use of electrical appliances, such as a hair dryer in the vicinity of a bath filled with water or a shower. There was also no description, how to safely replace a lightbulb. The question under the chapter aims to check the student's knowledge contained in the text. A student who uses the WSiP 4 PzP textbook is familiarized with

20 The following textbooks do not cover these topics: ABC 4, Wiking 4, Op 4, Żak 4, Klett 4, WSiP 4, ABC 4, Wiking 5, Era 5, WSiP 5 II PzP, Wiking 5, Op 6, Wiking 6, Klett 6, ABC 6, WSiP 6 PzP. the four principles of safety in using electrical appliances at home. In this textbook there is also no warning against disconnecting electrical plugs from power sources with wet hands. Pictures of electrical equipment bearing appropriate indications help students understand the safety rules of electrical equipment handling. The topic was not mentioned in the chapter summary. The questions under the text are reproductive.

The rules for safe handling of electrical equipment were described in Section 7, entitled "Electrical, Magnetic and Acoustic Phenomena in Nature", in the two chapters: 7.4. "Electricity - its sources and uses" and 7.7. "Safe use of electrical appliances". In chapter 7.4. the authors have provided information on how to properly connect the power supply to everyday devices such as vacuum cleaners, electric kettles, and electronic devices such as computers or printers, taking into account the voltage required on the rating plates of the devices. The text also explains why the knowledge of voltage is very important for the safe use of electrical appliances. The student learns that the effects of using a voltage that is too high can even result in the device becoming ignited. In the next sentence, the need to familiarize oneself with the voltage value requirements the devices is highlighted.

The text is diversified with several pictures of nameplates showing the voltages required by different electrical devices. It is important, because the theoretical knowledge can be immediately verified and used in practice by the student. This command is written in bold and italics, and aimed at the practical application of the knowledge acquired by the student by checking the voltage values specific to the electrical devices in the student home. The rules for safe use of electrical appliances are described in chapter 7.7. Specific rules are listed in a uniform text without any drawings or illustrations, which would certainly have a greater impact on the students' imagination, as well as their health awareness. In addition, some principles are described very broadly and are not supported by concrete examples of behaviour to be applied in everyday life. For example, there is no mention that you should not use electrical appliances, such as hair dryers, in the immediate vicinity of water, i.e. near a bathtub or a sink filled with water. This chapter deals with the very important issue of the possible consequences of actions that are reckless and incompatible with electrical safety regulations namely electric shocks. A student learns that electric shocks can cause serious health issues such as burns or even a heart attack. The next sentence deals with giving first aid to a person who has suffered an electric shock, with the concern for their own safety. However, the students are only told how to that by commanding them to disconnect the power supply and call for help as soon as possible. The concern for the condition of the natural environment is a very important element of taking care of our own health and the health of others. Therefore, the authors rightly point out that electrical appliances contain a lot of substances that are harmful to the environment, hence it is necessary to properly recycle them when they are no longer used. Picture 260 captioned "Waste batteries should be disposed of in special containers" on page 146 plays a role in encouraging students' to responsible and informed conduct with waste electrical or electronic equipment. Questions that are addressed at the end of the chapter, asking for specific student activities in their school that are related to the collection of waste batteries and electrical appliances are helpful in shaping the students' awareness and attitude. The pupil's competency test at the end of the chapter only relates to the student's knowledge. However, to raise the level of health education the tasks that appeal to the student's skills and health awareness would also be helpful. The issue of safe use of electrical equipment 
seems to be significant enough that it would also deserve more attention in the summarization at the end of the chapter. The topic of safe handling of electrical equipment is described in chapter $\mathrm{V}$ of the $\mathrm{ABC} 5$ textbook entitled "Electrical and magnetic phenomena in science". Household electrical appliances are described in the picture on page 205 in Chapter 2: "What is electric current?" This chapter also includes a photo of a marked container in which the used batteries should be stored. The photograph is accompanied by a brief note on the danger of the substances from which batteries and accumulators are built. In the next chapter of the handbook - "Though which substances a current flows?" - there are ten principles of safe use of electrical equipment and seven steps of first aid to a person experiencing electric shock. The essential information is provided by the authors in a tangible way. Of the eight questions at the end of the chapter "Though which substances a current flows?" only the last two are related to the safety issues of electrical appliances. It should be noted that none of them refer to the skills or health awareness of students. It is intended only for students to reproduce the knowledge acquired in this chapter. Another grade 5 textbook - Klett 5 lists six principles for safe use of household electrical appliances in Chapter 31 , entitled "Safe at work and during rest". Some appropriate and inappropriate behaviour related to this problem is depicted on the attached photos. The authors also point out how to behave when first aid is needed for a person shocked by electricity, but also about their own safety. Of the five questions at the end of the chapter, only one refers to the knowledge about the use of electrical appliances. It should be noted that the authors of the textbook remind of the safety rules in the summary at the end of the chapter. These issues are also addressed in Chapter 34, entitled "How does electricity work?". The authors point to this important topic in one sen- tence, and then refer to the knowledge that the students have already acquired. Among the questions that examine the student's acquired competences, at the end of this chapter, the last question relates to their ability to maintain safety while handling electrical power. However, in the chapter summary, this issue is completely omitted. In the Op-5 textbook, the issue is discussed in Chapter 5.2: "Safe and dangerous effects of electric currents." A drawing in which a boy named Michał wants to share his knowledge and skills on safe use of electrical appliances with his peers and siblings at the beginning of a chapter may play a prominent role in the development of health awareness among children learning in grade 5. However, this interesting way to familiarize students with these issues, which seems to involve the child's emotions in the process of acquiring knowledge and skills, is not continued throughout the chapter. The authors of the textbook present seven recommendations that must be followed when using electrical equipment, which is a fairly standard outlook. These recommendations are provided in a language that is accessible to and understood by 5 th grade students. A warning, accompanied by an exclamation point and printed in a different colour, alerting of a possible lethal danger of electricity from using an appliance in close proximity to the water, which is a good power conductor can definitely effect the child's imagination and emotion. One of the questions asked in the homework section tests the student's ability by indicating the situation in which the current can be dangerous to human health or life. The issue of safe use of electrical equipment has not been found in the knowledge summary at the end of the chapter. The WSiP 5 textbook lists several principles for safe use of electrical appliances. Some of them are presented in the form of illustrations, with appropriate descriptions. Students also have the opportunity to conduct and experiment testing whether a salt solution conducts electricity. Based on the experiment, they should conclude that using a hair dryer during bathing may cause an electric shock. The authors of the WSiP 5 I PzP textbook have listed six principles of safe use of household electrical appliances. Particular attention has been paid to the bathroom safety and to the situations in which we may be endangered by electric shocks. They have proposed an experiment to prove that water conducts electricity well. Therefore when we take baths, stand on a wet floor or have wet hands, we should not use electrical appliances. Two questions that test the students' knowledge and skills reflect on the safe use of electrical appliances in the bathroom - they are located under the chapters that discuss this topic: "The effects of an electrical current" and "Electricity in my home". The authors of the Żak 6 textbook give some principles of safe use of electricity. The text is accompanied by a single photo, which is intended to warn against careless handling of electrical sources. The questions under this chapter apply very broadly to all the dangerous situations that a student may encounter at home. In the WSiP 6 textbook, the problem was mentioned in one of the questions in a chapter that aims to recap information before middle school. The NE 6 textbook briefly informs students how to safely use electrical equipment. Under this chapter, the authors did not mention these issues.

\section{Summary and Conclusions}

It is difficult to overestimate health and its proper place in social life and in the life of the individual. The topic of health appears in the proverbs and in everyday discussions for both children and adults (Kirschner, 1992). Cisek and colleagues report that the level of health care depends on the level of education and a higher level of health awareness hence the level of education, occupation and social position is important 
Publishing house label according to table 4

\# $\quad$ Recording content

\begin{tabular}{|c|c|c|c|c|c|c|c|c|c|c|c|c|c|c|c|c|c|c|c|c|c|c|c|c|c|c|c|}
\hline \multicolumn{28}{|c|}{ Publishing house label according to table 4} \\
\hline \multicolumn{3}{|c|}{ Wiking } & \multicolumn{3}{|c|}{ Nowa Era 1} & \multicolumn{3}{|c|}{ Operon } & \multicolumn{3}{|c|}{ LektorKlett } & \multicolumn{3}{|c|}{ WSiP 1} & \multicolumn{4}{|c|}{ Nowa Era 2} & \multicolumn{3}{|c|}{ Żak } & \multicolumn{3}{|c|}{$A B C$} & \multicolumn{3}{|c|}{ WSiP 2} \\
\hline 1.1 & 1.2 & 1.3 & 2.1 & 2.2 & 2.3 & 3.1 & 3.2 & 3.3 & 4.1 & 4.2 & 4.3 & 5.1 & 5.2 & 5. & 6 & & & & 7.1 & 7.2 & 7.3 & 8.1 & 8.2 & 8.3 & 9.1 & 9.2 & 9.3 \\
\hline
\end{tabular}

1. Me and my surroundings. Student:

lists positive and negative influences on his or her well-being at

1 school and at home (...)

(...) suggests ways of eliminating negative factors

explains the importance of rest

2 (including sleep), nutrition and physical activity in the proper functioning of the body

lists the principles of correct

3 learning (...)

(...) applies them in life

4 describes a properly designed

4 learning place (...)

explains to the need to plan day

and week activities (...)

(...) correctly plans and executes his or her schedule (...)

(...) applies safety rules during natural observation

recognizes and names some plants (...) containing substances

9 that are poisonous (...)

(...) provides the rules for dealing with them

5. Man and the environment. Student:

5 gives examples of (...) environ-

mental impacts on human health

10. Electrical and magnetic phenomena in nature. Student:

(...) describes and applies the

4 principles of safe handling of

electrical appliances
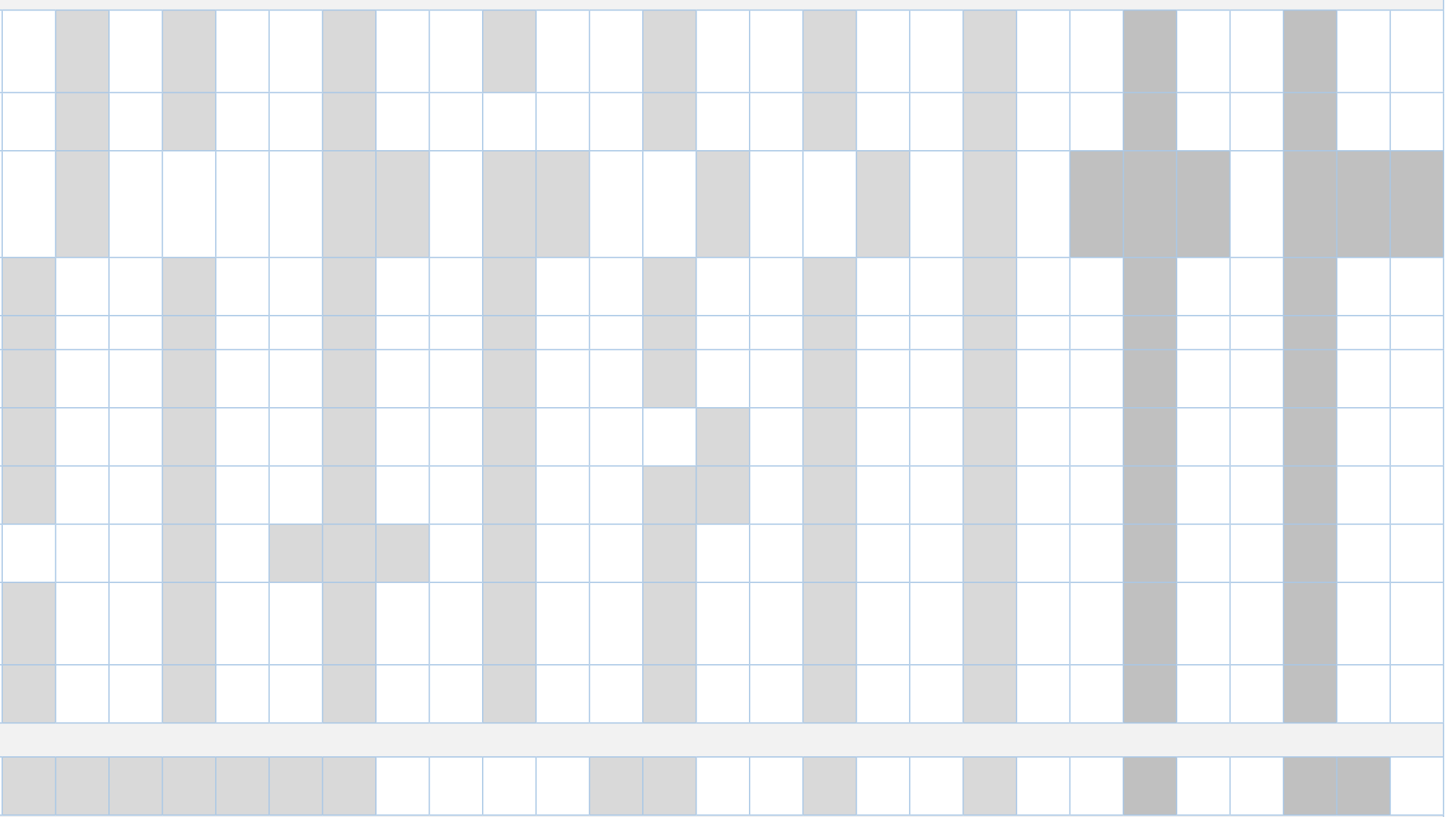

Table 5: Summary of the presence of specific content in the analysed textbooks

Grey indicates that this content was present in the textbook of the series 
(Cisek, Gniadek, Richter, Chmiel, 2004). Nowadays, in times of rapid technological development, unrestricted access to information and ubiquitous information clutter on the Internet (Tadeusiewicz, 1999) many people are trying to diagnose and cure themselves. This problem affects both adults and teenagers. In addition, it is worth noting that for many different reasons, anti-vaccination, homeopathic, bioenergy therapy or bioenergy healing and other types of "natural" treatment are becoming more and more popular nowadays.

In society (and also among children), there are many inaccuracies or misconceptions regarding health information. An analysis of interviews conducted with students from several secondary schools by Dr. Barbara Ostrowska from the Educational Research Institute, concerning the didactic tool presented below ${ }^{21}$ (teaching tool - drug leaflet) pose as an interesting example of it.

The following are excerpts from the information leaflet of a drug.

Description of action: the drug has anti-inflammatory, bronchodilatory and antiallergic properties.

Instructions of use:

- acute and chronic inflammation of the upper and lower respiratory tract,

bronchospasm,

otitis media.

Side effects:

gastrointestinal disorders, nausea, abdominal pain

drowsiness,

speed up heart function.

After a few days of using the presented medication, Ania experienced vomiting and abdominal pain.

21 Unpublished material, courtesy of Dr. Barbara Ostrowska from the Educational Research Institute. The analysis was carried out on 24 pupils and was related to a larger group of tools. In this task only 10 students answered correctly to both lines of the task.
Rate the truth of the following statements by circling $T$ True or F-False.

\begin{tabular}{|l|l|c|}
\hline No. & Statement & $\begin{array}{c}\text { True or } \\
\text { false }\end{array}$ \\
\hline 1. & $\begin{array}{l}\text { The girl's malaise may be a side effect of tak- } \\
\text { ing a medicine. }\end{array}$ & $\mathrm{T} / \mathrm{F}$ \\
\hline 2. & Ania may have food poisoning. & $\mathrm{T} / \mathrm{F}$ \\
\hline
\end{tabular}

Interviews were conducted to define what made it difficult for the students to solve the problem posed by the question. Interviews show that:

- The task introduction was not a problem, and students mostly answered correctly to the first questions.

- Interestingly - students do not identify the girl's malaise with abdominal pain and vomiting. In their opinion it is not based on physical symptoms. Thus, there is a misunderstanding of a (seemingly very simple and basic) concept of well-being that often appears in science textbooks in elementary school. It is most likely that the authors of the textbooks considered the concept to be so obvious that it does not need explaining.

Due to the aforementioned problems, the need for shaping health awareness among children seems to be more and more important. Stawiński states that: (...) from the very beginning of their education pupils should be aware of the need to care for their own health and the importance of hygienic practices. In parallel with mastering the necessary knowledge and skills, students should actively participate in acquiring habits and attitudes. A personal example, strong will and the ability to resist negative peer and elders' pressure (...) play a very important role in this (Stawiński, Walosik 2006). It is of utmost importance to place particular emphasis on the relevant provisions for shaping awareness and pro-health behaviour in educational documents. The publication details the 2009 and 2017 curriculums in terms of the preamble content as well as the learning objectives and content of the subjects taught in Science and Biology. Most records are repeated or highly compatible (Table 3). From the point of view of health records, the main difference between the curriculums is that some of the sub-points are disposed from the science curriculum to the science and biology (5-8) subjects in elementary school ${ }^{22}$. Of course, the provisions in educational documents will not themselves guarantee adequate education for children and young people. the role of teachers in the teaching-learning process is extremely important. ${ }^{23}$ Documents should, however, work as a guarantee that relevant records will be present in school textbooks. Of course, the presence of textbooks in school and for student self-study can be assessed both positively and negatively - this issue was not the subject of the publication. The problem of the presence of textbooks in school classes has been dealt with for many years by educators and researchers (Stasińska, 1983, Drynda 1998). The study, however, shows that the textbook, regardless of its form - paper or electronic - has been the basis of school education for many years (CNK, 2009). In an adequate report from the Educational Research Institute's Natural Sciences Institute: Diagnosis of primary school science teachers' needs for support, in conducting lessons, the research methodology shows that almost $90 \%$ of teachers use textbooks in each lesson. The teachers who

22 It is important to emphasize the importance of student's health awareness in the process of introducing new textbooks into primary schools.

23 According to the results of the IBE (Educational Research Institute) study: in practice students are not taught from ministerial documents but according to the school-adopted curriculum and using specific textbooks (IBE, Grajkowski, Ostrowska, Studzińska 2013). 
work in the field for over 14 years more often declared that the situation ([...] where students work individually with a textbook or exercise book) takes place almost in every lesson (IBE, Grajkowski 2014). Accordingly, it seems that the analysis of textbooks according to the aforementioned aspects is an important aspect in shaping healthy behaviours for future conscious citizens.

Based on the analysis of the textbooks mentioned in the chapter: Material and Methods, we can draw conclusions about the influence of these didactic measures on shaping the health awareness of elementary school pupils in science classes. All analysed textbooks may influence the student's health consciousness. It should be noted, however, that this effect is strongly differentiated in terms of frequency and types of tasks and activities proposed to students. Textbooks are usually focused on giving and describing concepts and providing definitions. There are also a number of exercises and tasks that shape skills and serve to reproduce information. All these competences are extremely important and are included in the core curriculum, but the need to shape the health consciousness of students is unfortunately often marginalized. It is worth to compare 20 examples of tasks taken from four randomly selected textbooks for teaching science in grade 4 from the sections related to 1.1 record of the core curriculum for the subject $\mathrm{Na}$ ture 1.1: lists positive and negative influences on his or her well-being at school and at home and proposes ways to eliminate the negative ones.

1. Write in two columns: the elements of your surroundings that are essential to your life, and the things that make life easier for you [Żak 4].

2. Count how many litres of water you drink per day (including: tea, soup, juices, mineral water and other liquids). Determine whether this quantity is sufficient [Żak 4].
3. List your actions that promote family bond development [Żak 4].

4. What are your feelings about the school and its surroundings? Write down what you would like to change [Żak 4].

5. List the positive and negative influences that affect your well-being at school and at home. [Żak 4].

6. Replace bad and favourable learning conditions [Skill 4].

7. Make your own schedule using the rules for proper scheduling. [Żak 4].

8. List the basic principles of learning [Klett 4].

9. Describe your place of study and assess whether it is properly designed. [Klett 4 ].

10. Explain the importance of rest (including sleep) for proper functioning of the body [Klett 4].

11. Plan your activities for one study day [Klett 4]

12. Plan your activities throughout the week, i.e. 7 days, including days off [Klett 4].

13. Suggest some sentences ending for: I like school because ... [NE 4].

14. Give examples of dangerous behaviour at school [NE 4].

15. Explain what a place to study at home should look like [NE 4].

16. List the principles of effective learning [NE 4].

17. Propose how you can help a shy person [WSiP 4].

18. Explain what you can do to be liked by others [WSiP 4].

19. Describe how you can help a person with a disability and how they can help you [WSiP 4].

20. Determine how to behave in order to feel good at school [WSiP 4].

Of course, the tasks presented are only a small part of the tasks placed in all the textbooks. As an example, however, they show that some commands (e.g., 2, 4, 5, 7, $8,11,12,18$, or 20) can influence the shaping of health awareness and of healthy lifestyle in particular by understanding how our simple, daily activities impact our health ${ }^{24}$. Health awareness includes general knowledge about factors and behaviours affecting health, and indirectly also our opinions on our influence on our health, motivation and ability to make pro-health choices - as suggested by Cisek. This is consistent with the definition given by Mazurkiewicz (Mazurkiewicz, 1978) and quoted by Korzeniowska (Korzeniowska, 1997) (...) among the definition of health behaviours are those which include the consciousness of the acting subject within a concept of behaviour. [...] E. Mazurkiewicz understands all behaviours / habits, customs, attitudes, values recognized by individuals and social groups / in the field of health as health behaviours.

All of the science textbooks for the second stage of education included in the study can be used to implement the assumptions of the core curriculum for general education. The content discussed in each textbook is exhaustive of the document, and often extends on it. ${ }^{25}$.

Students' health awareness manifests itself when they make a reflective analysis of various problem situations that are present in the textbook (Chrzanowski, Gawrońska, Aszklar, Piszczek, 2016). This awareness is often a reflection of their personal experience. While conducting this type of reflection a student can gain awareness of the value of healthy behaviour connected with even the simplest activities they perform during the day. This is certainly the foundation of the acquired knowledge and skills related to health in our own system of values.

24 Some of these tasks, unfortunately, were reproductive, as they referred to the text or illustrations in the textbook.

$25 \mathrm{It}$ is worth noting that most textbooks deal with issues discussed in the publication in textbooks for grade 4 of primary school (Table 5). 


\section{References}

Chrzanowski M, Gawrońska B, Aszklar A, Piszczek E (2016). Wymiar edukacji zdrowotnej w podręcznikach do przedmiotu Przyroda. W: Bieniek P, ed. Podręcznik do nauk przyrodniczych w XXI wieku. Kraków: Uniwersytet Pedagogiczny w Krakowie; 75-98.

Cisek M, Gniadek A, Richter B, Chmiel I (2004). Społeczno-kulturowe uwarunkowania zachowań zdrowotnych w rodzinie. Annales Universitatis Mariae Curie-Sktodowsk Lublin - Polonia, Secti 59:359-363.

CNK (2009). Wykorzystanie eksperymentów i metod aktywizujacych w nauczaniu - problemy i wyzwania. Raport $z$ badań. Warszawa: Pracownia Badań i Innowacji Społecznych Stocznia, Centrum Nauki Kopernik.

Drynda D (1998). Podręcznik szkolny w poglądach pedagogów i dydaktyków Drugiej Rzeczypospolitej: próby poszukiwania teorii podręcznika. Chowanna. 2:72-83.

Grysztar M, Duplaga M (2016). Przegląd interwencji z zakresu edukacji zdrowotnej adresowanych do młodzieży szkolnej. W: Chmielewski J, Wojciechowska M, Król H, ed. Zdrowie w wymiarze edukacyjnym i społecznym. Warszawa: Instytut Ochrony Środowiska - Państwowy Instytut Badawczy; 37-51.

IBE (2013). Podstawa programowa przedmiotów przyrodniczych w opiniach nauczycieli, dyrektorów szkół oraz uczniów - Raport tematyczny z badania. Warszawa: Instytut Badań Edukacyjnych.

IBE (2014). Diagnoza potrzeb nauczycieli przyrody w szkole podstawowej, $w$ zakresie wsparcia, $w$ prowadzeniu lekcji, metoda badawcza-Raport tematyczny $z$ badania. Warszawa: Instytut Badań Edukacyjnych.

Kirschner H (1992). Zdrowie i choroba - pojęcia i uwarunkowania. W: Celejowa I, Pawłowski M, ed. Edukacja ekologiczna i zdrowotna dzieci i młodzieży Materiały z Ogólnopolskiego Seminarium Naukowego. Warszawa: Stowarzyszenie Zdrowy Człowiek; 123130.

Korzeniowska E (1997). Zachowania i świadomość zdrowotna w sferze pracy. Łódź: Krajowe Centrum Promocji Zdrowia w Miejscu Pracy, Instytut Medycyny Pracy im. prof, dra med. J. Nofera.

Mazurkiewicz EA (1978). Podstawy wychowania zdrowotnego W: Brzeziński ZJ, Korczak CW, ed. Higiena i ochrona zdrowia. Warszawa: Państwowy Związek Wydawnictw Lekarskich; 377-400.

MEN (2009). Ministerstwo Edukacji Narodowej: Podstawa programowa z komentarzami, T.5. Edukacja przyrodnicza w szkole podstawowej, gimnazjum i liceum; przyroda, geografia, biologia, chemia, fizyka, MEN, 2009.

MEN (2017). Rozporządzenie Ministra Edukacji Narodowej z dnia 14 lutego 2017 r. w sprawie podstawy programowej wychowania przedszkolnego oraz podstawy programowej kształcenia ogólnego dla szkoły podstawowej, w tym dla uczniów z niepełnospraw- nością intelektualną w stopniu umiarkowanym lub znacznym, kształcenia ogólnego dla branżowej szkoły I stopnia, kształceni ogólnego dla szkoły specjalnej przysposabiającej do pracy oraz kształcenia ogólnego dla szkoły policealnej, MEN 2017.

http://www.dziennikustaw.gov.pl/DU/2017/356

Musialik M, Chrzanowski MM, Buczek I, Arèvalo-Garcia EB, Ostrowska EB, (2013). Elements of environmental education in the new Polish curriculum for teaching chemistry and selected chemistry textbooks at ISCED 2 and ISCED 3 level. Proceedings of ECOpole. 7:133-142.

Oleszkowicz A, Senejko A (2011). Dorastanie. W: Trempała J, Kielar-Turska M, Niemczyński A, Czerwińska-Jasiewicz M, ed. Psychologia rozwoju człowieka. Warszawa: Wydawnictwo Naukowe PWN; 259-286.

Pingel F (2009). UNESCO guidebook on textbook research and Textbook revision, Paris: United Nations Educational, Scientific and Cultural Organization.

http://unesdoc.unesco.org/images/0011/001171/117188e.pdf 01.02.2016.

Puchalski K (1994). Kryteria zdrowia w świadomości potocznej. Promocja Zdrowia, Nauki Społeczne i Medycyna. 1-2:53-69.

Sławiński S, Dębowski H, Michałowicz H, Urbanik J (2014). Słownik podstawowych terminów dotyczących krajowego systemu kwalifikacji Warszawa: Instytut Badań Edukacyjnych. http://uniwersytetradom.pl/files/get_userfile.php?id=7212, 01.02.2016.

Słońska Z (1994). Promocja zdrowia - zarys problematyki. Promocja Zdrowia, Nauki Spoteczne i Medycyna. 1-2:3 i 52.

Spis podręczników dopuszczonych do użytku szkolnego, Ministerstwo Edukacji Narodowej.

http://www.men.gov.pl/podreczniki/wykaz_dopuszczone_lista1. php, 10.07.2017

Stasińska K (1983). Z badań nad funkcjami podręcznika szkolnego do przedmiotu „Muzyka” w kl. 1. Zeszyty naukowe Wyższej Szkoty Pedagogicznej w Bydgoszczy - studia z wychowania muzycznego. 6:63-81.

Stawiński W, Walosik A (2006). Dydaktyka biologii i ochrony środowiska. Warszawa: Wydawnictwo Naukowe PWN.

Tadeusiewicz R (1999). Smog informacyjny. Prace Komisji Zagrożen Cywilizacyjnych - Polska Akademia Umiejętności. 2:97-107.

Woynarowska B (2009). Edukacja zdrowotna w nowej podstawie programowej kształcenia ogólnego w szkole - szansa i wyzwanie. Remedium 2:1-3.

Woynarowska B (2017). Edukacja zdrowotna - Podręcznik akademicki. Warszawa: Wydawnictwo Naukowe PWN.

\section{Acknowledgements}

The author thanks Dr. Barbara Ostrowska from the Educational Research Institute for providing the didactic tool that includes results of student interviews. 


\section{Appendix 1. List of abbreviations used to describe textbooks}

\begin{tabular}{|c|c|c|c|}
\hline $\begin{array}{l}\text { Code and number } \\
\text { of the textbook }\end{array}$ & Series title & Authors & Publishing house \\
\hline $\begin{array}{c}\mathrm{ABC} 4 \\
8.1\end{array}$ & Przyroda & $\begin{array}{l}\text { B. Gulewicz, B. } \\
\text { Brzozowska-Michałek, } \\
\text { A. Lauda-Michalska, } \\
\text { J. Piętka-Baumgart, B. } \\
\text { Ziółkowska }\end{array}$ & $A B C$ \\
\hline $\begin{array}{c}\text { Op } 4 \\
3.1\end{array}$ & $\begin{array}{l}\text { Ciekawi świata } 4 \text { Przy- } \\
\text { roda }\end{array}$ & $\begin{array}{l}\text { Małgorzata Augustows- } \\
\text { ka, Małgorzata Gajewska }\end{array}$ & Operon \\
\hline $\begin{array}{c}\text { Klett } 4 \\
4.1\end{array}$ & Przyroda z klasą & $\begin{array}{l}\text { Joanna Buniowska, Ewa } \\
\text { Frąckowiak, Ewa Gęca, } \\
\text { Przemysław Jeruszka }\end{array}$ & $\begin{array}{l}\text { Lektorklett } \\
\text { Poznań }\end{array}$ \\
\hline $\begin{array}{l}\text { WSiP } 4 \text { PzP } \\
\quad 9.1\end{array}$ & $\begin{array}{l}\text { Przyroda z pomysłem } \\
\text { część l ill }\end{array}$ & $\begin{array}{l}\text { Urszula Depczyk, Bożena } \\
\text { Sienkiewicz, Halina Bink- } \\
\text { iewicz }\end{array}$ & $\begin{array}{l}\text { Wydawnictwa } \\
\text { Szkolne i Peda- } \\
\text { gogiczne }\end{array}$ \\
\hline $\begin{array}{c}\text { Wiking } 4 \\
1.1\end{array}$ & $\begin{array}{l}\text { Przyroda poznać } \\
\text { i zrozumieć }\end{array}$ & $\begin{array}{l}\text { Brygida Baranowska, } \\
\text { Elżbieta Szedzianis, Rob- } \\
\text { ert Wers, Romana Woźnik }\end{array}$ & Wiking \\
\hline $\begin{array}{l}\text { WSiP } 4 \\
5.1\end{array}$ & Przyrodo, Witaj! & $\begin{array}{l}\text { E. Gromek, E. Kłos, W. } \\
\text { Kofta, E. Laskowska, A. } \\
\text { Melson }\end{array}$ & $\begin{array}{l}\text { Wydawnictwa } \\
\text { Szkolne i Peda- } \\
\text { gogiczne }\end{array}$ \\
\hline $\begin{array}{c}\text { Era } 4 \\
6.1\end{array}$ & Na tropach przyrody & $\begin{array}{l}\text { Marcin Braun, Wojciech } \\
\text { Grajkowski, Marek } \\
\text { Więckowski }\end{array}$ & Nowa Era \\
\hline $\begin{array}{l}\text { Żak } 4 \\
7.1\end{array}$ & Przyroda & $\begin{array}{l}\text { B. Klimuszko, J. } \\
\text { Sokołowska, M. } \\
\text { Wilczyńska-Wołoszyn }\end{array}$ & $\begin{array}{l}\text { Żak Wydawnict- } \\
\text { wo Edukacyjne } \\
\text { Zofii Dobkowskiej }\end{array}$ \\
\hline $\begin{array}{l}\mathrm{ABC} 5 \\
8.2\end{array}$ & Przyroda & $\begin{array}{l}\text { Barbara Gulewicz, Anna } \\
\text { Lauda-Michalska, Joanna } \\
\text { Piętka-Baumgart, Beata } \\
\text { Ziółkowska }\end{array}$ & $A B C$ \\
\hline $\begin{array}{l}\text { Op } 5 \\
3.2\end{array}$ & $\begin{array}{l}\text { Ciekawi Świata } 5 \text { Przy- } \\
\text { roda }\end{array}$ & $\begin{array}{l}\text { Małgorzata Augustows- } \\
\text { ka, Elżbieta Bytniewska, } \\
\text { Małgorzata Gajewska, } \\
\text { Marzena Karwowska }\end{array}$ & Operon \\
\hline $\begin{array}{c}\text { Klett } 5 \\
4.2\end{array}$ & Przyroda z klasą & $\begin{array}{l}\text { Ewa Frąckowiak, Ewa } \\
\text { Gęca, Joanna Buniowska }\end{array}$ & $\begin{array}{l}\text { LektorKlett } \\
\text { Poznań }\end{array}$ \\
\hline $\begin{array}{c}\text { NE } 5 \\
2.2\end{array}$ & Tajemnice Przyrody & $\begin{array}{l}\text { Janina Ślósarczyk, } \\
\text { Ryszard Kozik, Feliks } \\
\text { Szlajfer }\end{array}$ & Nowa Era \\
\hline
\end{tabular}

\begin{tabular}{|c|c|c|c|}
\hline $\begin{array}{l}\text { WSiP } 5 \text { I PzP } \\
\quad 9.2\end{array}$ & $\begin{array}{l}\text { Przyroda z pomysłem } \\
\text { Część I }\end{array}$ & $\begin{array}{l}\text { Urszula Depczyk, Bożena } \\
\text { Sienkiewicz, Halina Bink- } \\
\text { iewicz }\end{array}$ & $\begin{array}{l}\text { Wydawnictwa } \\
\text { Szkolne i Peda- } \\
\text { gogiczne }\end{array}$ \\
\hline $\begin{array}{l}\text { WSiP } 5 \text { II PzP } \\
\quad 9.2\end{array}$ & $\begin{array}{l}\text { Przyroda z pomysłem } \\
\text { Częśćll }\end{array}$ & $\begin{array}{l}\text { Urszula Depczyk, Bożena } \\
\text { Sienkiewicz, Halina Bink- } \\
\text { iewicz }\end{array}$ & $\begin{array}{l}\text { Wydawnictwa } \\
\text { Szkolne i Peda- } \\
\text { gogiczne }\end{array}$ \\
\hline $\begin{array}{c}\text { Wiking } 5 \\
1.2\end{array}$ & $\begin{array}{l}\text { Przyroda poznać } \\
\text { i zrozumieć }\end{array}$ & $\begin{array}{l}\text { Brygida Baranowska, } \\
\text { Elżbieta Szedzianis, Rob- } \\
\text { ert Wers, Romana Woźnik }\end{array}$ & Wiking \\
\hline $\begin{array}{l}\text { WSiP } 5 \\
5.2\end{array}$ & Przyrodo, Witaj! & $\begin{array}{l}\text { Ewa Gromek, Ewa Kłos, } \\
\text { Wawrzyniec Kofta, Ewa } \\
\text { Laskowska, Andrzej } \\
\text { Melson }\end{array}$ & $\begin{array}{l}\text { Wydawnictwa } \\
\text { Szkolne i Peda- } \\
\text { gogiczne }\end{array}$ \\
\hline $\begin{array}{c}\text { Era } 5 \\
6.2\end{array}$ & Na tropach przyrody & $\begin{array}{l}\text { Marcin Braun, Wojciech } \\
\text { Grajkowski, Marek } \\
\text { Więckowski }\end{array}$ & Nowa Era \\
\hline $\begin{array}{c}\text { Żak } 5 \\
7.2\end{array}$ & Przyroda & $\begin{array}{l}\text { Berenika Targos-Panak, } \\
\text { Maria M. Wilczyńska- } \\
\text { Wołoszyn }\end{array}$ & $\begin{array}{l}\text { Żak Wydawnict- } \\
\text { wo Edukacyjne } \\
\text { Zofii Dobkowskiej }\end{array}$ \\
\hline $\begin{array}{l}\text { Op } 6 \\
3.3\end{array}$ & $\begin{array}{l}\text { Ciekawi Świata } 6 \text { Przy- } \\
\text { roda }\end{array}$ & $\begin{array}{l}\text { Małgorzata Augustows- } \\
\text { ka, Elżbieta Bytniewska, } \\
\text { Małgorzata Gajewska, } \\
\text { Marzena Karwowska }\end{array}$ & Operon \\
\hline $\begin{array}{c}\text { Wiking } 6 \\
1.3\end{array}$ & $\begin{array}{l}\text { Przyroda poznać } \\
\text { i zrozumieć }\end{array}$ & $\begin{array}{l}\text { Brygida Baranowska, } \\
\text { Elżbieta Szedzianis, Rob- } \\
\text { ert Wers, Romana Woźnik }\end{array}$ & Wiking \\
\hline $\begin{array}{c}\text { Klett } 6 \\
4.3\end{array}$ & Przyroda z klasą & $\begin{array}{l}\text { Ewa Frąckowiak, Ewa } \\
\text { Gęca, Joanna Buniowska }\end{array}$ & $\begin{array}{l}\text { LektorKlett } \\
\text { Poznań }\end{array}$ \\
\hline $\begin{array}{c}\mathrm{ABC} 6 \\
8.3\end{array}$ & Przyroda & $\begin{array}{l}\text { B. Gulewicz, A. Lauda- } \\
\text { Michalska, J. Piętka- } \\
\text { Baumgart, B. Ziółkowska }\end{array}$ & $A B C$ \\
\hline $\begin{array}{c}\text { Żak } 6 \\
7.3\end{array}$ & Przyroda & $\begin{array}{l}\text { L. Bober, B. Targos-Panak, } \\
\text { M. Wilczyńska-Wołoszyn }\end{array}$ & $\begin{array}{l}\text { ŻakWydawnictwo } \\
\text { Edukacyjne Zofii } \\
\text { Dobkowskiej }\end{array}$ \\
\hline $\begin{array}{l}\text { WSiP } 6 \text { PzP } \\
\quad 9.3\end{array}$ & $\begin{array}{l}\text { Przyroda z pomysłem } \\
\text { część l ill }\end{array}$ & $\begin{array}{l}\text { Urszula Depczyk, Bożena } \\
\text { Sienkiewicz, Halina Bink- } \\
\text { iewicz }\end{array}$ & $\begin{array}{l}\text { Wydawnictwa } \\
\text { Szkolne i Peda- } \\
\text { gogiczne }\end{array}$ \\
\hline $\begin{array}{l}\text { WSiP } 6 \\
5.3\end{array}$ & Przyrodo, Witaj! & $\begin{array}{l}\text { E. Gromek, E. Kłos, W. } \\
\text { Kofta, E. Laskowska, A. } \\
\text { Melson }\end{array}$ & $\begin{array}{l}\text { Wydawnictwa } \\
\text { Szkolne i Peda- } \\
\text { gogiczne }\end{array}$ \\
\hline $\begin{array}{l}\text { NE } 6 \\
2.3\end{array}$ & Tajemnice Przyrody & $\begin{array}{l}\text { Joanna Stawarz, Feliks } \\
\text { Szlajfer, Hanna Kowalczyk }\end{array}$ & Nowa Era \\
\hline
\end{tabular}

